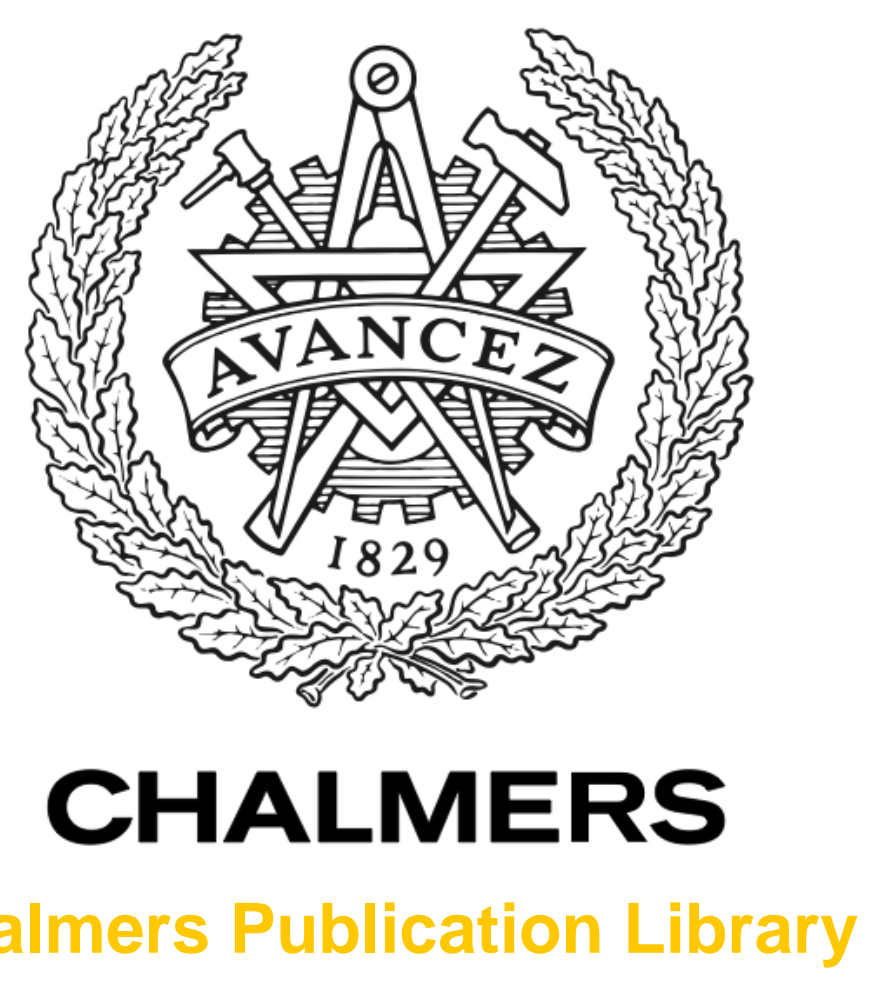

Chalmers Publication Library

\title{
Effects of Different Substituents on the Crystal Structures and Antimicrobial Activities of Six Ag(I) Quinoline Compounds
}

This document has been downloaded from Chalmers Publication Library (CPL). It is the author's version of a work that was accepted for publication in:

Inorganic Chemistry (ISSN: 0020-1669)

Citation for the published paper:

Massoud, A. ; Langer, V. ; Gohar, Y. (2013) "Effects of Different Substituents on the Crystal Structures and Antimicrobial Activities of Six Ag(I) Quinoline Compounds". Inorganic

Chemistry, vol. 52(7), pp. 4046-4060.

http://dx.doi.org/10.1021/ic400081v

Downloaded from: http://publications.lib.chalmers.se/publication/177961

Notice: Changes introduced as a result of publishing processes such as copy-editing and formatting may not be reflected in this document. For a definitive version of this work, please refer to the published source. Please note that access to the published version might require a subscription. 


\title{
The effects of different substituents on the crystal structures and antimicrobial activities of six $\operatorname{Ag}(I)$ quinoline compounds
}

\author{
Alshima'a A. Massoud*a ${ }^{a}$, Vratislav Langer ${ }^{a}$, Yousry M. Gohar ${ }^{b}$, Morsy A. M. Abu-Youssef ${ }^{c}$, Janne Jänis ${ }^{d}$, \\ Gabriella Lindberg ${ }^{e}$, Karl Hansson ${ }^{a}$ and Lars Öhrström*a \\ ${ }^{a}$ Dept. of Chemical and Biological Engineering, Chalmers University of Technology, SE-412 96 Gothenburg, Sweden. Fax: +4631772 \\ 3858; E-mail: shimo_chem@hotmail.com; langer@chalmers.se; hanssonk@student.chalmers.se ohrstrom@chalmers.se; Tel: +46 31772 \\ 2871 ; \\ ${ }^{b}$ Dept. of Microbiology, Alexandria University, P.O. Box 426 Ibrahimia, 21321 Alexandria, Egypt; E-mail: ymgohar@yahoo.com \\ ${ }^{c}$ Chemistry Dept., Alexandria University, P.O. Box 426 Ibrahimia, 21321 Alexandria, Egypt; E-mail: morsy5@link.net \\ ${ }^{d}$ Dept. of Chemistry, University of Eastern Finland, P.O. Box 111, FI-80101, Joensuu, Finland, E-mail: janne.janis@uef.fi \\ e Encubator AB, Vera Sandbergs Allé 8, SE-41296, Gothenburg, Sweden, E-mail: gabriella.cj.lindberg@gmail.com
}

\section{Abstract}

The syntheses and single crystal X-ray structures of $\left[\mathrm{Ag}(5 \text {-nitroquinoline })_{2}\right] \mathrm{NO}_{3} \quad \mathbf{1}, \quad[\mathrm{Ag}(8-$ nitroquinoline $\left.)_{2}\right] \mathrm{NO}_{3} \cdot \mathrm{H}_{2} \mathrm{O} \quad \mathbf{2}, \quad\left[\mathrm{Ag}(6-\text { methoxy-8-nitroquinoline })\left(\mathrm{NO}_{3}\right)\right]_{n} \quad \mathbf{3}, \quad[\mathrm{Ag}(3-$ quinolinecarbonitrile $\left.)\left(\mathrm{NO}_{3}\right)\right]_{n} \mathbf{4},\left[\mathrm{Ag}(3 \text {-quinolinecarbonitrile })_{2}\right] \mathrm{NO}_{3} \mathbf{5}$, and $[\mathrm{Ag}(6$-quinolinecarboxylic acid $)_{2} \mathrm{NO}_{3} 6$ are described. As an alternative to solution chemistry solid state grinding could be used to prepare compounds $\mathbf{1}$ and $\mathbf{3}$ but the preparation of $\mathbf{4}$ and $\mathbf{5}$ in this way failed. The $\operatorname{Ag}(\mathrm{I})$ ions in the monomeric compounds $\mathbf{1}, \mathbf{2}, \mathbf{5}$, and $\mathbf{6}$ are coordinated to two ligands via the nitrogen atoms of the quinoline rings, thereby forming a distorted linear coordination geometry with Ag-N bond distances of 2.142(2)-2.336(2) $\AA$ and N-Ag-N bond angles of $163.62(13)-172.25(13)^{\circ}$. The $1 \mathrm{D}$ coordination polymers 3 and 4 contain $\operatorname{Ag}(\mathrm{I})$ centers coordinating one ligand and two bridging nitrate groups, thereby forming a distorted trigonal planar coordination geometry with $\mathrm{Ag}-\mathrm{N}$ bond distances of 2.2700(14) $\AA$ and 2.224(5) $\AA$, Ag-O bond distances of 2.261(4)-2.536(5) $\AA$, and N-Ag-O bond angles of 115.23(5)-155.56(5) ${ }^{\circ}$. Hirshfeld surface analyses of compounds 1-6 are presented as $d_{\text {norm }}$ and curvedness maps. The $d_{\text {norm }}$ maps show different interaction sites around the $\mathrm{Ag}(\mathrm{I})$ ions, i.e., $\mathrm{Ag}$... Ag interactions and possible O-H...O, C-H...O, C-H...N, and C-H...C hydrogen bonds. Curvedness maps are a good way of visualizing $\pi-\pi$ stacking interactions between molecules. The antimicrobial activities of compounds 1, 2, and $\mathbf{6}$ were screened against 15 different Multi-Drug Resistant Strains (MDRS) of bacteria isolated from diabetic foot ulcers, and compared to the antimicrobial activities of the clinically used silver sulfadiazine (SS). Compound 2 showed activity similar to SS against this set of test organisms, being active against all strains and having slightly better average silver efficiency than SS (5 $\mu \mathrm{g} \mathrm{Ag} / \mathrm{ml}$ vs. $6 \mu \mathrm{g} \mathrm{Ag} / \mathrm{ml}$ ). Against the standard non-resistant bacterial strains of Staphylococcus aureus, Pseudomonas aeruginosa, Proteus mirabilis, and Streptococcus pyogenes, compound 1 performed better than silver nitrate, with an average MIC of $6 \mu \mathrm{g} \mathrm{Ag} / \mathrm{ml}$ versus $18 \mu \mathrm{g} \mathrm{Ag} / \mathrm{ml}$ for the 
reference $\mathrm{AgNO}_{3}$. Electrospray ionization mass spectrometry (ESI-MS) analyses of compounds 3 and $\mathbf{6}$ in DMSO/MeOH confirm the two-coordinated $\mathrm{Ag}^{+}$complexes in solution, and the results of the ${ }^{1} \mathrm{H}-$ NMR titrations of DMSO solutions of 5-nitroquinoline and 8-nitroquinoline with $\mathrm{AgNO}_{3}$ in $\mathrm{DMSO}$ suggests that 5-nitroquinoline is more strongly coordinated to the silver ion.

\section{Keywords}

Ag(I) compounds, X-ray structures, quinoline compounds, Hirshfeld surface analysis, antimicrobial activity, ESI-MS.

\section{Introduction}

As the problems associated with multi-drug resistant strains (MDRS) of bacteria are serious and increasing, ${ }^{1}$ the chemical and pharmaceutical sectors community cannot leave any stone unturned in the quest for solutions. Silver and $\mathrm{Ag}(\mathrm{I})$ compounds, especially silver sulfadiazine, are used clinically to prevent infections in burns and wounds, ${ }^{2}$ and they appear to have potential against MDRS. However, while the in vitro antimicrobial effect of silver-containing wound dressings is undisputed, clinical efficacy has not been demonstrated unequivocally, ${ }^{3}$ due to difficulties with in vivo testing and because these materials are considered medical devices rather than drugs, and are therefore not subject to the same regulations. An additional concern is the potential development by bacteria of resistance to silver and the possible coupling of this to antibiotic resistance, which means that the appropriate use of silver compounds may be a difficult balancing act. ${ }^{4}$ It should be noted that the biological activities of silvercontaining compounds have also been assessed for purposes other than wound healing. ${ }^{5}$

More efficient ways are needed for exploiting the antimicrobial properties of silver-containing compounds, so as to minimize the overall exposure to silver, both for medical and environmental ${ }^{6}$ reasons. Research is ongoing in many laboratories, with only a few recent examples cited here. ${ }^{7} \mathrm{We}$ have reported that silver compounds with nicotinic acid derivatives are active against clinical isolates of MDRS of Staphylococcus aureus, Streptococcus pyogenes, Proteus mirabilis, and Pseudomonas aeruginosa. ${ }^{8}$ These compounds showed stronger in vitro bactericidial activities than silver sulfadiazine against these organisms, with the exception of $S$. aureus, against which the drugs had similar activities. $^{2 \mathrm{a}}$

As a extension of these structural ${ }^{9}$ and antimicrobial ${ }^{10}$ studies, we here present information on the synthesis and X-ray structures of six new $\mathrm{Ag}(\mathrm{I})$ compounds (1-6) with quinoline-derived ligands (Chart 
1). The antimicrobial activities of compounds 1, 2 and 6 for 15 MDRS isolated from diabetic foot ulcers were examined, using silver sulfadiazine as the standard. In addition, compound $\mathbf{1}$ was also screened against four standard laboratory bacterial strains in both a Minimum Inhibitory Concentration (MIC) test and a time-kill experiment.

The rationale for using quinoline-type ligands is that they have been shown to be biologically active; 4and 8-aminoquinoline-based compounds are used as anti-HIV and anti-malaria drugs, as well as pharmacologic antagonists in neurotoxin poisoning. ${ }^{11}$ In addition, alkyl-quinolines have high toxicity for aquatic bacteria and fish, which is correlated with the alkyl chain length and positions of the substituents. $^{12}$<smiles>O=[N+]([O-])c1cccc2ncccc12</smiles>

(a)<smiles>O=[N+]([O-])c1cccc2cccnc12</smiles>

(b)<smiles>COc1cc([N+](=O)[O-])c2ncccc2c1</smiles>

(c)<smiles>N#Cc1cnc2ccccc2c1</smiles>

(d)<smiles>O=C(O)c1ccc2ncccc2c1</smiles>

(e)

Chart 1: Quinoline derivatives used for the synthesis of compounds 1-6: (a) 5-nitroquinoline, 5-nqu (for 1); (b) 8nitroquinoline, 8-nqu (for 2); (c) 6-methoxy-8-nitroquinoline, mnqu (for 3); (d) 3-quinolinecarbonitrile, quc (for 4 \& 5); and (e) 6-quinolinecarboxylic acid, quCOOH (for 6).

Another advantage of quinoline ligands is their structural features. We are especially interested in how the $\pi-\pi$ stacking, which is one of the important interactions between molecules that contain fused polycyclic aromatic rings (e.g., quinolines), affects the overall structure of these $\mathrm{Ag}(\mathrm{I})$ complexes. Does the $\pi-\pi$ stacking override, or perhaps enhance, the $\operatorname{Ag}(\mathrm{I})$ preference for linear coordination? Is the hard nitrate ion forced into contact with the silver ion to avoid the highly hydrophobic environment of the fused rings, or is the water of crystallization "used" by the nitrate ion to reduce its charge and hardness? As a complementary tool to individual atom-atom geometry measurements, we have 
visualized the intermolecular interactions through analyses of the Hirshfeld surfaces. ${ }^{13}$ We have also compared compounds 1-6 to the known structures of unsubstituted quinoline $\mathrm{Ag}(\mathrm{I})$ compounds.

A search of the Cambridge Crystallographic Database $(\mathrm{CSD})^{14}$ revealed $55 \mathrm{Ag}(\mathrm{I})$ structures with different quinoline-type ligands, although compounds based on the ligands used in the present study were not found. The crystal structures of the pure ligands, with the exception of 6-quinolinecarboxylic $\operatorname{acid}^{15}$, have not been determined to date.

It should be noted that $\mathrm{Ag}(\mathrm{I})$ coordination geometries with pyridine-type ligands are extremely flexible, and are on the brink of being unpredictable. This has lead to an enormous variety of coordination polymers (note that this term is currently under IUPAC review ${ }^{16}$ ): e.g., the pyrazines reviewed recently by Steel and Fitchett, ${ }^{17}$ and the 1D cases examined by Champness and co-workers in $2001 .{ }^{18}$ Previously, we investigated the structures in the CSD that contain silver, a pyridine fragment, and a nitrate counter ion, and we found a correlation between the N-Ag-N angle and the Ag...O distances. ${ }^{19}$ Recently, it has been suggested that in the case of hydrophobic ligands that have hydrophilic substituents, the nitrate groups tend to be either assembled around $\operatorname{Ag}(\mathrm{I})$ ions or hydrogen-bonded to the hydrophilic substituents of the ligand. ${ }^{10 a}$

With respect to biological activity, it is important to consider the chemistries in solution of silver and compounds thereof, ${ }^{20}$ as speciation in solution is likely to be an important factor. Therefore, we performed electrospray ionization (ESI) MS studies on compounds 3 and 6 in DMSO/MeOH, and ${ }^{1} \mathrm{H}-$ NMR titrations of DMSO solutions of 5-nitroquinoline and 8-nitroquinoline with $\mathrm{AgNO}_{3}$ corresponding to compounds $\mathbf{1}$ and $\mathbf{2}$.

\section{Experimental}

Materials and Instrumentation. All chemicals and solvents were of analytical grade and used without further purification. All preparations and manipulations were performed under aerobic conditions. Infrared spectra were recorded on a Bruker IFS-125 model FT-IR spectrophotometer as $\mathrm{KBr}$ pellets. Powder X-ray diffraction patterns were recorded on Siemens Smart D5000 powder diffractometer. High-resolution ESI-MS analyses were performed on a Bruker APEX-Qe hybrid quadrupole Fourier antiform ion cyclotron resonance (Q-FT-ICR) mass spectrometer, equipped with an Apollo-II ESI source and a 4.7-T superconducting magnet. The instrument was operated in both 
positive and negative ion modes. Elemental analyses were performed by Mikroanalytisches Laboratorium Kolbe (Mülheim an der Ruhr, Germany).

\section{NMR spectroscopy}

NMR spectra were recorded in DMSO- $d_{6}$ on a Varian VNMR-S $500 \mathrm{MHz}$ spectrometer thermostated at $298 \mathrm{~K}$ with the solvent as internal standard. The solid forms of $\mathbf{1}$ and $\mathbf{2}$ were dissolved in DMSO- $d_{6}$. For the titration experiments, the starting concentration of 5-nitroquinoline was $4.60 \mathrm{mM}$ and this solution was titrated with a $4.87-\mathrm{mM}$ solution of $\mathrm{AgNO}_{3}$, while the starting concentration of 8nitroquinoline was $3.85 \mathrm{mM}$ and this solution was titrated with a $7.85-\mathrm{mM}$ solution of $\mathrm{AgNO}_{3}$. After the additions, the solutions were mixed with a vortex stirrer, reinserted in the probe, and the ${ }^{1} \mathrm{H}-\mathrm{NMR}$ spectra were recorded. The residual solvent peak was monitored to ensure that no drift occurred.

X-ray crystallography. Crystallographic measurements were made on a Siemens Smart CCD diffractometer with graphite-monochromated Mo Ka radiation $(\lambda=0.71073 \AA)$ at 173 or $153 \mathrm{~K}$. CCD data were integrated with the SAINT package ${ }^{21}$ and a multi-scan absorption correction was applied using $S A D A B S{ }^{22}$ All structures were solved by direct methods and refined against all $F^{2}$ data by fullmatrix least-squares $\left(S H E L X L 97^{23}\right)$, including anisotropic displacement parameters for all non-H atoms. Hydrogen atoms were refined isotropically with use of geometrical constrains: aromatic hydrogen atoms were refined for all compounds isotropically with $U_{\mathrm{iso}}(\mathrm{H})=1.2 U_{\mathrm{eq}}(\mathrm{C})$, and their positions were constrained to an ideal geometry using a riding model, $(\mathrm{C}-\mathrm{H}=0.95 \AA)$. For compound 2, the water hydrogens were located on the difference Fourier map and refined with restraints on

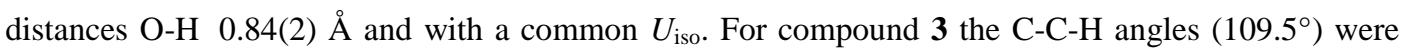
kept fixed for the methyl hydrogens, while the torsion angle was allowed to refine with the starting positions based on the circular Fourier synthesis averaged using the local 3-fold axis with $U_{\text {iso }}(\mathrm{H})$ $=1.5 U_{\text {eq }}(\mathrm{C})$, and a constrained $\mathrm{C}-\mathrm{H}$ distance of $0.98 \AA$ was applied. For compound $\mathbf{6}, \mathrm{C}-\mathrm{O}-\mathrm{H}$ angles $\left(109.5^{\circ}\right)$ were kept fixed for the hydroxy group hydrogens while the torsion angles were allowed to refine with the starting positions based on the circular Fourier synthesis with $U_{\text {iso }}(\mathrm{H})=1.5 U_{\text {eq }}(\mathrm{O})$, and a constrained O-H distance of $0.84 \AA$ was applied. The relatively large residuals of 2-6 are in the vicinity of the $\mathrm{Ag}$ atoms in all cases.

CCDC 803814 - 803819 contain the supplementary crystallographic data for compounds 1-6. These data can be obtained free of charge from the Cambridge Crystallographic Data Center via http://www.ccdc.cam.ac.uk/data_request/cif . 


\section{Synthesis of compounds 1-6}

1 [Ag(5-nqu) $)_{2} \mathrm{NO}_{3}$ To an aqueous solution $\left(20 \mathrm{~cm}^{3}\right)$ of $\mathrm{AgNO}_{3}(0.34 \mathrm{~g}, 2.0 \mathrm{mmol})$ was added an ethanolic solution $(20 \mathrm{ml})$ of 5-nitroquinoline $(0.70 \mathrm{~g}, 4 \mathrm{mmol})$. A white microcrystalline precipitate formed immediately and was filtered and dried in air $(0.83 \mathrm{~g}, 91 \%)$. Good quality single crystals could be grown from more dilute solutions. The powder X-ray diffraction of the bulk material shows no sign of any amorphous phase and there was a complete match with the peaks from a diffractogram simulated from single crystal data (Fig. S7). Larger quantities could be prepared by the solid state route, grinding 1:2 ratios of silver nitrate and the ligand for $20 \mathrm{~min}$ in a mortar, heating to $150^{\circ} \mathrm{C}$ for 20 min. and subsequent re-grinding for $5 \mathrm{~min}$. Powder X-ray diffraction showed no sign of any amorphous phase and matched the diffractogram simulated from single crystal data. The dry powder is hygroscopic and a partly hydrated sample, $\mathrm{C}_{18} \mathrm{H}_{14.6} \mathrm{AgN}_{5} \mathrm{O}_{8.3}$, gave the following elemental analysis: calc: C, 39.92; H, 2.72; N, 12.93, found: C, 39.52; H, 2.31; N, 12.85. ${ }^{1} \mathrm{H}$ NMR (DMSO- $d_{6}, 298 \mathrm{~K}$ ): $\delta$, $7.82(1 \mathrm{H}, \mathrm{d}), 7.97(1 \mathrm{H}, \mathrm{d}), 8.44(1 \mathrm{H}, \mathrm{t}), 8.46(1 \mathrm{H}, \mathrm{dt}), 8.85(1 \mathrm{H}, \mathrm{dd}), 9.08(1 \mathrm{H}, \mathrm{dd}){ }^{13} \mathrm{C}$ NMR (DMSO$d_{6}, 298 \mathrm{~K}$ ): $\delta, 153.2,127.5,127.9,131.5,134.7,139.1$ (quaternary carbons were not observed) FT-IR, $\mathrm{KBr}\left(\mathrm{cm}^{-1}\right)$ (v, very; s, strong; m, medium; w, weak; br, broad; sh, shoulder): $2924 \mathrm{w}, 2851 \mathrm{w}, 1592 \mathrm{w}$, 1520 vs, 1410 sh, 1383 vs, 1360 sh, 1337 sh, 1319 sh, 1215 m, 1138 m, 878 m, 830 m, 794 s, 730 m, 574 m, br, 502 m, 408 m, 388 m, 366 m, 343 m, 316 m, 293 m, 270 s, 234 s.

2 [Ag(8-nqu $\left.)_{2}\right] \mathrm{NO}_{3} \cdot \mathbf{H}_{2} \mathbf{O}$ To an aqueous solution $\left(20 \mathrm{~cm}^{3}\right)$ of $\mathrm{AgNO}_{3}(0.37 \mathrm{~g}, 2.2 \mathrm{mmol})$ was added an ethanolic solution $(15 \mathrm{ml})$ of 8 -nitroquinoline $(0.77 \mathrm{~g}, 4.3 \mathrm{mmol})$. After five days in the dark at room temperature, pale green fine needles suitable for X-ray diffraction had formed. These were filtrated and dried in air giving $0.57 \mathrm{~g}(49 \%)$. The powder X-ray diffraction of the bulk material shows no sign of any amorphous phase and there was a complete match with the diffractogram simulated from single crystal data. A partly dehydrated sample, $\mathrm{C}_{18} \mathrm{H}_{14} \mathrm{AgN}_{5} \mathrm{O}_{7.5}$, gave the following elemental analysis: calc: C, 41.01; H, 2.49; Ag, 20.46; N, 13.28, found: C, 41.43; H, 2.42; Ag, 20.61; N, 13.50. ${ }^{1} \mathrm{H}$ NMR $\left(\mathrm{DMSO}-d_{6}, 298 \mathrm{~K}\right): \delta, 7.73-7.78(2 \mathrm{H}, \mathrm{m}), 8.26(1 \mathrm{H}, \mathrm{dd}), 8.29(1 \mathrm{H}, \mathrm{dd}), 8.58(1 \mathrm{H}, \mathrm{dd}), 9.04(1 \mathrm{H}, \mathrm{dd})$

${ }^{13} \mathrm{C}$ NMR (DMSO- $d_{6}, 298 \mathrm{~K}$ ): $\delta, 126.3,126.4,129.0,135.1,139.7,155.9$ (quaternary carbons were not observed) FT-IR, KBr ( $\mathrm{cm}^{-1}$ ) (v, very; s, strong; m, medium; w, weak; br, broad; sh, shoulder) $3060 \mathrm{~m}$, 2304 m, 2035 m, 2007 m, 1625 s, 1595 s, 1566 m, 1530 vs, 1467 s, 1448 s, 1427 s, 1383 vs, 1243 s, 1215 s, 1168 s, 1136 s, 1079 s, 1045 s, 972 w, 933 w, 877 vs, 830 vs, 789 vs, 765 vs, 722 s, 681 m, 646 s, 453 s, 405 s, 387 s, 365 s, 342 s, 315 s, 293 s, 270 s. 
$3\left[\mathbf{A g}(\mathbf{m n q u})\left(\mathbf{N O}_{3}\right)\right]_{n}$ To an aqueous solution $\left(20 \mathrm{~cm}^{3}\right)$ of $\mathrm{AgNO}_{3}(0.34 \mathrm{~g}, 2.0 \mathrm{mmol})$ was added an ethanolic solution $(20 \mathrm{ml})$ of 6-methoxy-8-nitroquinoline $(0.80 \mathrm{~g}, 4 \mathrm{mmol})$. After a few days in the dark at room temperature, colorless crystals suitable for X-ray diffraction had formed. Larger quantities could be prepared by the solid state route, grinding equimolar quantities of silver nitrate and 6methoxy-8-nitroquinoline for $20 \mathrm{~min}$ in a mortar, heating to $150^{\circ} \mathrm{C}$ for $20 \mathrm{~min}$. and subsequent regrinding for $5 \mathrm{~min}$. Powder X-ray diffraction showed no sign of any amorphous phase and matched the diffractogram simulated from single crystal data (Fig. S8). The dry powder is hygroscopic and a partly hydrated sample, $\mathrm{C}_{10} \mathrm{H}_{9.4} \mathrm{AgN}_{3} \mathrm{O}_{6.7}$ gave: calc.: C, 31.06; H, 2.45; N, 10.87, and found: C, 31.44; $\mathrm{H}$, 2.84; N, 10.98. $\mathrm{m} / \mathrm{z}$ calc. 515.0121 found 515.0166; FT-IR, $\mathrm{KBr}\left(\mathrm{cm}^{-1}\right)$ (v, very; s, strong; m, medium; w, weak; br, broad; sh, shoulder): 2917 w, 2839 w, 1627 s, 1595 m, 1569 m, 1536 vs, 1494 s, 1468 m, 1449 s, 1429 m, 1383 vs, 1361 sh, 1336 s, 1245 s, 1157 m, 1131 m, 1045 s, 1029 m, 934 w, 892 w, 878 w, 849 m, 786 m, 756 m, 715 w, 643 m, 593 m, 531 m, 508 m, 444 m, 408 m, 387 m, 365 m, 342 m, $316 \mathrm{~m}, 293 \mathrm{~m}, 270 \mathrm{~s}, 235$ vs.

4 and 5 were obtained from the same solution in an approximately 4:1 ratio by adding an ethanolic solution $(20 \mathrm{ml})$ of 3-quinolinecarbonitrile $(0.60 \mathrm{~g}, 4 \mathrm{mmol})$ to an aqueous solution $\left(20 \mathrm{~cm}^{3}\right)$ of $^{\mathrm{AgNO}_{3}}$ $(0.34 \mathrm{~g}, 2.0 \mathrm{mmol})$. After a few days in the dark at room temperature, colorless needles of $\mathbf{4}$, $\left[\mathrm{Ag}(\mathrm{quc})\left(\mathrm{NO}_{3}\right)\right]_{n}$ and colorless crystals of $\mathbf{5},\left[\mathrm{Ag}(\mathrm{quc})_{2}\right] \mathrm{NO}_{3}$ had formed. These were filtrated and dried in air. FT-IR, KBr $\left(\mathrm{cm}^{-1}\right)$ (v, very; s, strong; m, medium; w, weak; br, broad; sh, shoulder), Compound 4: 3057 m, 2305 m, 2226 s, 1762 m, 1615 s, 1595 m, 1570 m, 1535 w, 1518 w, 1491 s, 1461 sh, 1378 vs, br, 1305 vs, br, 1128 s, 985 s, 923 s, 869 m, 825 m, 783 s, 765 s, 748 s, 702 m, 683 m, 592 m, 471 m, 438 m, 407 m, 387 m, 366 m, 342 m, 316 m, 299 m, 270 s, 231 s. Compound 5: 3048 m, 2308 m, 2228 s, 1661 w, 1644 w, 1616 s, 1594 m, 1579 m, 1552 m, 1518 m, 1465 vs, 1449 s, 1368 vs, br, 1128 s, 988 s, 943 m, 920 s, 861 m, 835 m, 784 s, 768 s, 632 m, 472 s, 435 sh, 387 s, 366 s, 343 s, 316 s, 293 s, 270 vs.

Grinding 1:1 and 1:2 ratios of silver nitrate and 3-quinolinecarbonitrile for $20 \mathrm{~min}$ in a mortar, heating to $150^{\circ} \mathrm{C}$ for $20 \mathrm{~min}$. and subsequent re-grinding for $5 \mathrm{~min}$. did not produce compounds 4 and 5 but instead gave microcrystalline mixtures with unidentifiable powder diffractograms. The new materials are, however, solid well above the melting point of 3 -quinolinecarbonitrile $\left(108-110^{\circ} \mathrm{C}\right)$ indicating new but alas unknown products.

$6\left[\mathrm{Ag}(\mathbf{q u C O O H})_{2}\right] \mathrm{NO}_{3}$ To aqueous solutions $\left(20 \mathrm{~cm}^{3}\right)$ of $\mathrm{AgNO}_{3}(0.34 \mathrm{~g}, 2.0 \mathrm{mmol})$ was added an ethanolic solution $(20 \mathrm{ml})$ of $4 \mathrm{mmol} 6$-quinoline carboxylic acid $(0.70 \mathrm{~g})$ with continuous stirring. 
Initially, gel formation was observed, a few drops of $0.1 \mathrm{M} \mathrm{HNO}_{3}$ was added to the gel formed, the mixture heated and then filtered and the filtrate kept in the dark at room temperature. After a few days very pale yellowish crystals suitable for single crystal X-ray measurements had formed. These were dried in air to give a yield of approximately $85 \% . \mathrm{C}_{20} \mathrm{H}_{14} \mathrm{AgN}_{3} \mathrm{O}_{7}$ gave the following elemental analysis: calc: $\mathrm{C}, 46.53 ; \mathrm{H}, 2.73$; N, 8.14, found: $\mathrm{C}, 46.62 ; \mathrm{H}, 2.85 ; \mathrm{N}, 7.97 \mathrm{~m} / \mathrm{z}$ calc: 452.9999 , found: 453.0040. FT-IR, $\operatorname{KBr}\left(\mathrm{cm}^{-1}\right)$ (v, very; s, strong; m, medium; w, weak; br, broad; sh, shoulder): $3457 \mathrm{~s}$, br, 2920 w, 2778 w, 2425 s, br, 1936 m, br, 1914 m, br, 1691 s, 1627 s, 1581 m, 1552 w, 1534 w, 1502 s, 1459 s, 1382 vs, 1359 sh, 1329 s, 1279 vs, 1217 vs, 1196 sh, 1126 m, 1096 m, 1056 m, 1032 m, 960 w, 911 w, 854 w, 804 s, 787 s, 754 s, 638 s, 586 m, 516 s, 463 m, 407 w, 485 m, 343 s, 316 m, 293 m, $270 \mathrm{~s}, 232 \mathrm{~s}$.

Determination of Minimum Inhibitory Concentration (MIC). The antimicrobial activities of compounds 1-2 and 6 were determined according to the recommendations of the National Committee for Clinical Laboratory Standards (NCCLS; 1999) using the broth microdilution method. Evaluations of the minimum inhibitory concentrations (MICs) of the tested compound were conducted using 12 different clinical isolates of bacteria (collected at the Department of Vascular Surgery, Faculty of Medicine, Alexandria University, Egypt). The strains, all of which were resistant to commonly used antibiotics included six Gram-negative bacteria(Corynebacterium sp., Enterobacteriaceae, Neisseria polysaccharea, Pasteurella lymphangitidis, Micrococcus sp., Burkholderia mallei) and six Grampositive bacteria (Capnocytophaga cynodegmi, Stenotrophomonas maltophila, Bacillus sp., Alloiococcus otitidis, Stomatococcus mucilaginosus, and Staphylococcus sp.). The test materials were dissolved in DMSO to give a stock solutions that were subsequently diluted in the growth medium to give final concentrations of $256,128,64,32,16,8,2,1$, and $0.5 \mu \mathrm{g}$ of compound/ml. A final concentration of 5\% DMSO was present in all assays, a concentration which had no antimicrobial effect on its own (a control treatment, with all the tested bacteria using 10\% DMSO showed no antimicrobial activity). Bacteria were cultured in Mueller Hinton broth (MHB) for $24 \mathrm{~h}$ at $35^{\circ} \mathrm{C}$. For the standard bacterial strains of Staphylococcus aureus ATCC 25923 (CCUG 17621), Pseudomonas aeruginosa ATCC 10145(CCUG 551), Proteus mirabilis ATCC 29906 (CCUG 26767), and Streptococcus pyogenes ATCC 12344 (CCUG 4207), an incubation temperature of $37^{\circ} \mathrm{C}$ was used. The MIC value corresponded to the lowest concentration that inhibited the bacterial growth.

Time-kill assays of $\mathrm{AgNO}_{3}$ and $\mathbf{1}$ were determined following the Clinical and Laboratory Standards Institute (CLSI) (formerly the National Committee for Clinical Laboratory Standards) 
recommendations. Each experiment was performed in four repetitions, and the mean value was calculated. For the quantitative time-kill assays. 96-well tissue culture plates (Nunc ${ }^{\mathrm{TM}}$, LC-156545F96_MW_Plates) were used. Each antimicrobial agent was diluted from its stock solution using cationadjusted Mueller Hinton broth (CAMHB,90922 Mueller Hinton Broth 2; Sigma-Aldrich) to 0.5× MIC, MIC, $2 \times$ MIC, and 5× MIC values determined in the earlier antibacterial susceptibility testing. A growth control without antibacterial agent, along with a sterility control that lacked both the antibacterial agent and bacterial culture, was used for quality control. The bacterial culture was prepared using the direct colony suspension inoculum method. The numbers of viable cells were determined by measuring the optical density at $650 \mathrm{~nm}\left(\mathrm{OD}_{650}\right)$ using a spectrophotometer (EMax Endpoint ELISA Microplate Reader) and $1 \mathrm{McFarland}$ standard, and confirmed by post-CFU plate counting as a quality control step. PBS was used as the diluent to give a final concentration of $1 \times 10^{6-}$ $5 \times 10^{6} \mathrm{CFU} / \mathrm{ml}$, and the 96-well tissue culture plates were inoculated with the bacterial culture within 15 minutes of turbidity adjustment. The initial $\mathrm{OD}_{650}$ was measured immediately, thus ensuring background subtraction and normalization.

The plates were incubated at $37^{\circ} \mathrm{C}$ under aerobic conditions. The CLSI guidelines for antibacterial susceptibility determination of streptococcal species required incubation in $46 \% \mathrm{CO}_{2}$ at $37^{\circ} \mathrm{C}$.

The time-kill kinetics were determined at $0,1,2,3,4,5,6,7,8,9,17$, and $24 \mathrm{~h}$ after initial incubation, measured as the $\mathrm{OD}_{650}$ and confirmed with post-CFU plate counting as quality control. The activities of the antimicrobials were determined by plotting the $\mathrm{OD}_{650}$ values against time.

\section{Results and Discussion}

Syntheses. The compounds were synthesized by the direct mixing of $\mathrm{AgNO}_{3}$ (in water) and the corresponding quinoline derivatives (dissolved in ethanol) at a molar ratio of 1:2. This simple preparation procedure resulted in the crystallization of: $\left[\mathrm{Ag}(5-\mathrm{nqu})_{2}\right] \mathrm{NO}_{3} \mathbf{1} ;\left[\mathrm{Ag}(8-\mathrm{nqu})_{2}\right] \mathrm{NO}_{3} \cdot \mathrm{H}_{2} \mathrm{O} 2$; $\left[\mathrm{Ag}(\mathrm{mnqu})\left(\mathrm{NO}_{3}\right)\right]_{n} \mathbf{3} ;\left[\mathrm{Ag}(\mathrm{quc})\left(\mathrm{NO}_{3}\right)\right]_{n} \mathbf{4} ;\left[\mathrm{Ag}(\mathrm{quc})_{2}\right] \mathrm{NO}_{3}$ 5; and $\left[\mathrm{Ag}(\mathrm{quCOOH})_{2}\right] \mathrm{NO}_{3}$ 6. Compounds $\mathbf{1}, \mathbf{2}, \mathbf{5}$, and $\mathbf{6}$ maintained the 1:2 (Ag:L) stoichiometry of the reaction mixture, while compounds $\mathbf{3}$ and 4 instead gave crystals with a 1:1 (Ag:L) stoichiometry in which the nitrate groups are coordinated to the $\operatorname{Ag}(\mathrm{I})$ centers. The different coordination geometries around the $\operatorname{Ag}(\mathrm{I})$ ions in compounds 1-6 are shown schematically in Chart 2. Compounds $\mathbf{4}$ and $\mathbf{5}$ were obtained from the same reaction mixture with different chemical and structural formulae and yields (compound $\mathbf{5}$ constitutes approximately $80 \%$ and compound $420 \%$ of the overall product). 
Compounds $\mathbf{1}$ and $\mathbf{3}$ were also prepared by solid-state grinding. However, trials to make pure samples of compounds $\mathbf{4}$ and $\mathbf{5}$ in this way failed. In this case new solid products, indicated by a substantial increase in melting temperature, with unidentifiable powder X-ray diffractograms were obtained.

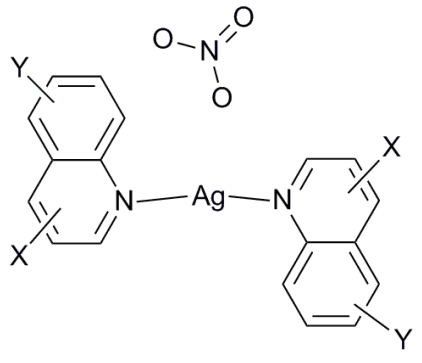

(a)

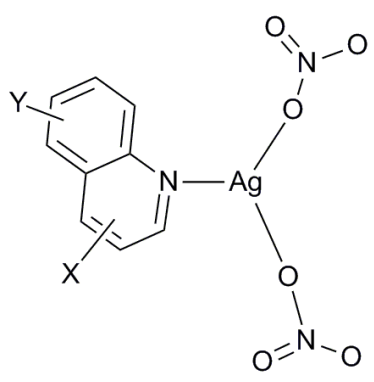

(b)

Chart 2: The different coordination geometries for compounds 1-6. (a) Linear coordination model for compounds 1, 2, 5, and 6; Ag-N bond distances, 2.14-2.34 $\AA$; N-Ag-N bond angles, 164-172 . (b) Trigonal planar coordination model for compounds 3 and 4; Ag-N bond distances, 2.22-2.27; Ag-O bond distances, 2.26 $2.54 \AA$; N-Ag-O bond angles, 115-156 ${ }^{\circ}$. The substituents are: $\mathrm{X}, \mathrm{C} \equiv \mathrm{N}$; and $\mathrm{Y},-\mathrm{NO}_{2},-\mathrm{OCH}_{3}$ or $-\mathrm{COOH}$.

IR spectra. The solid-state IR spectra of compounds 1, 2, and $\mathbf{3}$ show very strong overlapping absorption bands at $1382,1383,1520,1530$, and $1536 \mathrm{~cm}^{-1}$, which are assigned to the $v_{\mathrm{NO} 3}$ and $v_{\mathrm{NO} 2}$ groups, respectively. The strong bands at $1045 \mathrm{~cm}^{-1}$ and $1245 \mathrm{~cm}^{-1}$ observed for compound 3 are assigned to the $v_{\mathrm{C}-\mathrm{O}}$ group. For compounds 4 and $\mathbf{5}$, the $\left(v_{\mathrm{NO} 3}\right)$ bands appear at $1378 \mathrm{~cm}^{-1}$ and $1368 \mathrm{~cm}^{-1}$ and the $v_{\mathrm{C}=\mathrm{N}}$ bands are evident at $2226 \mathrm{~cm}^{-1}$ and $2228 \mathrm{~cm}^{-1}$, respectively. For compound $\mathbf{6}$, the $v_{\mathrm{NO} 3}$ bands appears at $1382 \mathrm{~cm}^{-1}$. Two strong bands at $1691 \mathrm{~cm}^{-1}$ and $1627 \mathrm{~cm}^{-1}$ for the $v_{\mathrm{C}=\mathrm{O}}$ group and at $3457 \mathrm{~cm}^{-1}$ and $2425 \mathrm{~cm}^{-1}$ for the $v_{\mathrm{O}-\mathrm{H}}$ group indicate the presence of $\mathrm{COOH}$ groups with different hydrogen bonding environments.

Structures. The $d^{10} \mathrm{Ag}(\mathrm{I})$ ion usually adopts linear, trigonal planar, and tetrahedral coordination geometries. Compounds 1-6 are linear or trigonal around the Ag centers depending on whether or not the nitrate is coordinated. The basic crystallographic data are listed in Table 1 and a detailed discussion follows below.

In addition to the newly synthesized structures, we used the unsubstituted quinoline (qu) compounds $\mathrm{Ag}(\mathrm{I})$ perchlorate $\left[\mathrm{Ag}(\mathrm{qu})_{2}\right] \mathrm{ClO}_{4}{ }^{24}$ (denoted $\mathbf{A}$ ), and $\mathrm{Ag}(\mathrm{I})$ nitrate $\left[\mathrm{Ag}_{2}(\mathrm{qu})_{4}\left(\mathrm{NO}_{3}\right)_{2}\right]^{24}$ (denoted $\mathbf{B}$ ) as reference compounds, to investigate the effects of substituents at different positions of the quinoline rings on the crystal structures of $\mathbf{1 - 6}$. In $\mathbf{A}$, the $\mathrm{Ag}(\mathrm{I})$ ion coordinates two quinoline ligands, forming a 
linear coordination geometry with an Ag-N bond distance of 2.128(4) $\AA$ and an N-Ag-N bond angle of $180^{\circ}$. Compound $\mathbf{B}$ has a dimeric structure in which each $\operatorname{Ag}(\mathrm{I})$ ion is coordinated to two quinoline ligands and one nitrate group forms a distorted trigonal planar coordination geometry with Ag-N bond distances of 2.19(4), 2.23(3), 2.20(4), and 2.26(4) $\AA$ and Ag-O bond distances of 2.51(5) $\AA$ and 2.65(5) $\AA$, while the $\mathrm{N}-\mathrm{Ag}-\mathrm{N}$ bond angles are $142.7(12)$ and $144.1(13)^{\circ}$. In both compounds, the aromatic rings of the quinoline ligands are oriented anti to each other. ${ }^{24}$

Hirshfeld surface analysis The strength of the $\pi$ - $\pi$ stacking interaction is primarily dependent upon three parameters: the centroid-centroid distance $(\sim 3.8 \AA)$; the angle $(\beta)$ between the normal to the ring; and a vector between the ring centroids $\left(\sim 20^{\circ}\right)^{25}$. However, this interaction can also be visualized using the so-called 'Hirshfeld surfaces'. This is a geometrical representation used to illustrate intermolecular interactions, such as $\pi-\pi$ stacking and hydrogen bonding, in supramolecular structures. Even weak interactions, such as C-H..., C...H, and H...H contacts, which are sometimes difficult to identify and are important for crystal packing, can be clearly observed. ${ }^{13 a, 13 d}$ The Hirshfeld surface is defined by $\mathrm{w}(\mathrm{r})=0.5$, where the weight function $\mathrm{w}(\mathrm{r})$ is given by:

$$
w(r)=\frac{\sum_{i \in \text { molecule }} \rho_{i}(r)}{\sum_{i \in \text { crystal }} \rho_{i}(r)}
$$

The weight function represents the ratio of the sum of spherical atom electron densities for a molecule to a similar sum for the whole crystal. ${ }^{13 \mathrm{c}}$ In the present study, we mapped the Hirshfeld surfaces as normalized contact distances $d_{\text {norm}}$, defined in terms of $d_{\mathrm{i}}, d_{\mathrm{e}}$ and the van der Waals radii of the atoms using the following color scheme: red (distances shorter than the sum of the van der Waals radii); and white through to blue (distances longer than the sum of the van der Waals radii). The curvedness of the Hirshfeld surfaces are presented with the following color scheme: green (flat surfaces); and blue (the edges). ${ }^{13 \mathrm{~b}, 13 \mathrm{~d}}$

The crystal structures and the Hirshfeld maps for $\mathbf{A}$ and $\mathbf{B}$ are shown in Figure 1. The red regions of the $d_{\text {norm }}$ that appear in Figure 1, a and $\mathrm{d}$ are due to the $\mathrm{Ag} \ldots \mathrm{Cl}, \mathrm{H} \ldots \mathrm{Cl}, \mathrm{Ag} \ldots \mathrm{O}$, and $\mathrm{O} \ldots \mathrm{H}$ interactions with adjacent counter-ions for each structure. The curvedness maps (Figure 1, b and c) of $\mathbf{A}$ show more flattened surfaces and therefore stronger $\pi-\pi$ stacking for the linear compound $\mathbf{A}$ than for the trigonal planar compound B (Figure 1e). 


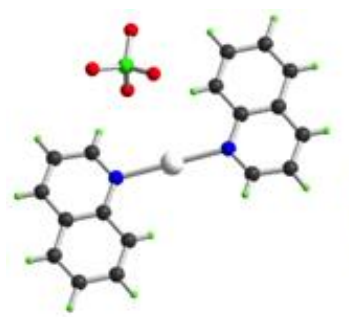

Compound (A)

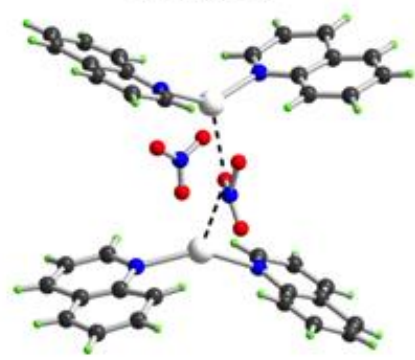

Compound (B)

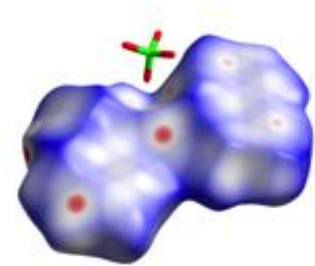

(a)

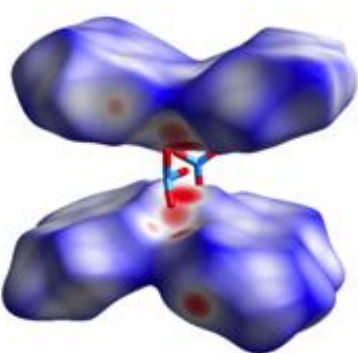

(d)

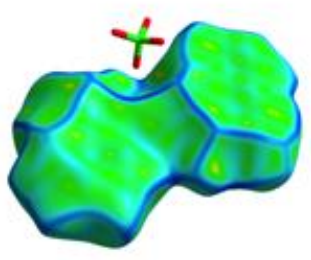

(b)

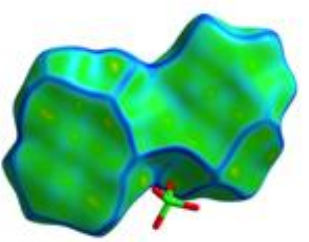

(c)

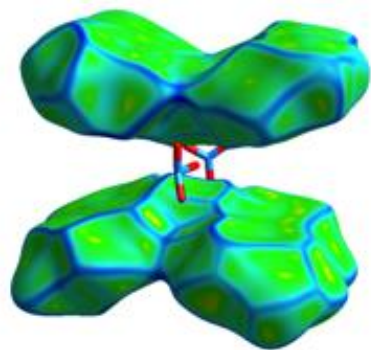

(c)

Figure 1: Compound A: (a) $d_{\text {norm }}$ map; (b) curvedness map (front view); and (c) curvedness map (back view). Compound B: (d) $d_{\text {norm }}$ map; and (e) curvedness map. 
Table 1: Crystallographic parameters of compounds 1-6.

\begin{tabular}{|c|c|c|c|c|c|c|}
\hline Parameter & 1 & 2 & 3 & 4 & 5 & 6 \\
\hline Chemical formula & $\mathrm{C}_{18} \mathrm{H}_{12} \mathrm{AgN}_{5} \mathrm{O}_{7}$ & $\mathrm{C}_{18} \mathrm{H}_{14} \mathrm{AgN}_{5} \mathrm{O}_{8}$ & $\mathrm{C}_{20} \mathrm{H}_{16} \mathrm{Ag}_{2} \mathrm{~N}_{6} \mathrm{O}_{12}$ & $\mathrm{C}_{10} \mathrm{H}_{6} \mathrm{AgN}_{3} \mathrm{O}_{3}$ & $\mathrm{C}_{20} \mathrm{H}_{12} \mathrm{AgN}_{5} \mathrm{O}_{3}$ & $\mathrm{C}_{40} \mathrm{H}_{28} \mathrm{Ag}_{2} \mathrm{~N}_{6} \mathrm{O}_{14}$ \\
\hline Formula weight & 518.20 & 536.21 & 748.13 & 324.05 & 478.22 & 1032.42 \\
\hline $\mathrm{T}(\mathrm{K})$ & $153(2)$ & $173(2)$ & $153(2)$ & $173(2)$ & $173(2)$ & $153(2)$ \\
\hline Crystal system & Monoclinic & Triclinic & Monoclinic & Monoclinic & Monoclinic & Triclinic \\
\hline Space group & $\mathrm{C} 2 / \mathrm{c}$ & $\mathrm{P}^{-} 1(\# 2)$ & $\mathrm{P} 2_{1} / \mathrm{c}$ & $\mathrm{P} 2_{1} / \mathrm{c}$ & $\mathrm{C} 2 / \mathrm{c}$ & $\mathrm{P}^{-} 1(\# 2)$ \\
\hline $\mathrm{a}(\AA)$ & $9.6050(9)$ & $7.9616(6)$ & $7.3567(7)$ & $14.140(4)$ & $23.249(3)$ & $8.4656(8)$ \\
\hline $\mathrm{b}(\AA)$ & $12.8009(12)$ & $15.4490(12)$ & $18.0436(18)$ & $9.621(3)$ & $9.9554(12)$ & $10.271(1)$ \\
\hline c $(\AA)$ & $14.4899(14)$ & $15.8779(12)$ & $9.1905(9)$ & $7.429(2)$ & $7.5745(10)$ & $12.4453(12)$ \\
\hline$\alpha\left({ }^{\circ}\right)$ & & $98.573(2)$ & & & & $67.326(2)$ \\
\hline$\beta\left(^{\circ}\right)$ & $98.665(2)$ & $90.058(2)$ & $110.107(2)$ & $98.177(6)$ & $91.828(2)$ & $76.277(2)$ \\
\hline$\gamma\left({ }^{\circ}\right)$ & & $94.064(2)$ & & & & $66.925(2)$ \\
\hline$V\left(\AA^{3}\right)$ & 1761.2(3) & 1926.2(3) & 1145.61(19) & $1000.3(5)$ & $1752.2(4)$ & $913.86(15)$ \\
\hline Z & 4 & 4 & 2 & 4 & 4 & 1 \\
\hline$\rho_{\text {calc }}\left(\mathrm{g} \mathrm{cm}^{-1}\right)$ & 1.954 & 1.849 & 2.169 & 2.152 & 1.813 & 1.876 \\
\hline$\mu\left(\mathrm{mm}^{-1}\right)$ & 1.204 & 1.108 & 1.793 & 2.013 & 1.185 & 1.157 \\
\hline $\mathrm{F}(000)$ & 1032 & 1072 & 736 & 632 & 952 & 516 \\
\hline Crystal size $\left(\mathrm{mm}^{3}\right)$ & $0.20 \times 0.16 \times 0.16$ & $0.72 \times 0.09 \times 0.04$ & $\begin{array}{l}0.48 \times 0.08 \times \\
0.08\end{array}$ & $\begin{array}{l}0.64 \times 0.16 \times \\
0.06\end{array}$ & $\begin{array}{l}0.10 \times 0.05 \times \\
0.04\end{array}$ & $0.22 \times 0.20 \times 0.10$ \\
\hline$\theta\left({ }^{\circ}\right)$ & $2.7-31.5$ & $1.3-30.0$ & $2.3-33.0$ & $2.6-25.0$ & $2.2-30.8$ & $2.3-32.9$ \\
\hline Collected reflections & 15519 & 30276 & 20580 & 10537 & 13903 & 16774 \\
\hline Unique reflections / R (int) & $2945 / 0.146$ & $11163 / 0.036$ & $4116 / 0.036$ & $1771 / 0.083$ & $2721 / 0.066$ & $6442 / 0.037$ \\
\hline Completeness of $\theta$ range (\%) & 99.9 & 99.3 & 95.3 & 99.9 & 99.5 & 99.6 \\
\hline Data / restraints / parameters & $2945 / 0 / 142$ & $11163 / 4 / 590$ & $4116 / 0 / 182$ & $1771 / 0 / 154$ & $2721 / 0 / 139$ & $6442 / 0 / 282$ \\
\hline Goodness-of-fit on $\mathrm{F}^{2}$ & 0.99 & 0.99 & 1.00 & 1.01 & 1.03 & 1.00 \\
\hline $\mathrm{R} 1 / \mathrm{wR} 2(\mathrm{I}>2 \sigma)$ & $0.0460 / 0.0704$ & $0.0412 / 0.0802$ & $0.0286 / 0.0778$ & $0.0540 / 0.1395$ & $0.0417 / 0.0954$ & $0.0309 / 0.0760$ \\
\hline R1 / wR2 (all data) & $0.1202 / 0.0833$ & $0.0601 / 0.0872$ & $0.0376 / 0.0843$ & $0.0660 / 0.1522$ & $0.0659 / 0.1076$ & $0.0409 / 0.0816$ \\
\hline Largest diff peak and hole $\left(\mathrm{e} . \mathrm{A}^{-3}\right)$ & 0.88 and -0.81 & 0.99 and -1.07 & 1.40 and -1.08 & 2.80 and -1.69 & 1.55 and -1.57 & 1.28 and -0.80 \\
\hline
\end{tabular}




\section{Structural descriptions for compounds 1-6}

Of the six $\operatorname{Ag}(\mathrm{I})$ compounds examined in the present study, four are monomeric $(\mathbf{1}, \mathbf{2}, \mathbf{5}$, and $\mathbf{6})$ and two are 1D-coordination polymers ( 3 and $\mathbf{4})$. They all have distorted linear and trigonal planar coordination geometries around the $\operatorname{Ag}(\mathrm{I})$ ions, depending on whether or not the nitrate is coordinated. We have previously reported a correlation between the N-Ag-N bond angles and Ag...O bond distances with nitrate groups as counter-ions, and shown that the stronger the $\mathrm{Ag}$... O interaction, the greater the $\mathrm{N}-\mathrm{Ag}-\mathrm{N}$ bond angle, thereby accounting for the trigonal planar geometry. ${ }^{19}$ Recently, we proposed that this interaction could be interpreted on the bases of the hydrophilic and hydrogen bonding properties of the ligands. Thus, in the case of hydrophobic ligands having hydrophilic substituents, the nitrate groups tend to be either assembled around the $\mathrm{Ag}(\mathrm{I})$ ions or are hydrogen-bonded to the hydrophilic substituents of the ligand. In the case of a stronger hydrophobic environment, a trigonal coordination geometry and an $\mathrm{Ag}-\mathrm{ONO}_{2}$ bond were more likely to be observed. ${ }^{10 \mathrm{a}}$

Here, we will first discuss the individual compounds and examine how their structures accord with the hydrophobicity concept. Thereafter, we will analyze the Hirshfeld surfaces of the structures.

\section{$\left[\mathrm{Ag}(5-\mathrm{nqu})_{2}\right] \mathrm{NO}_{3}, 1$}

The atom numbering scheme is shown in Figure 2. The $\operatorname{Ag}(\mathrm{I})$ ion is coordinated to two 5-nqu ligands, each via the nitrogen atom of the quinoline ring, forming a distorted linear coordination geometry with $\mathrm{Ag}-\mathrm{N}$ bond distances and an $\mathrm{N}-\mathrm{Ag}-\mathrm{N}$ bond angle comparable to those of the linear compound $\mathbf{A}$ (see Table 2). The 5-substituted aromatic rings of the quinoline moieties are anti to each other, as in compounds $\mathbf{A}$ and $\mathbf{B}$, and are not co-planar. Both the $\mathrm{Ag}(\mathrm{I})$ and $\mathrm{NO}_{3}$ groups are positioned on a two-fold axis, although there is no direct interaction between these groups; the shortest $\mathrm{Ag} . . . \mathrm{O}$ distance is 3.778(2) $\AA$. 


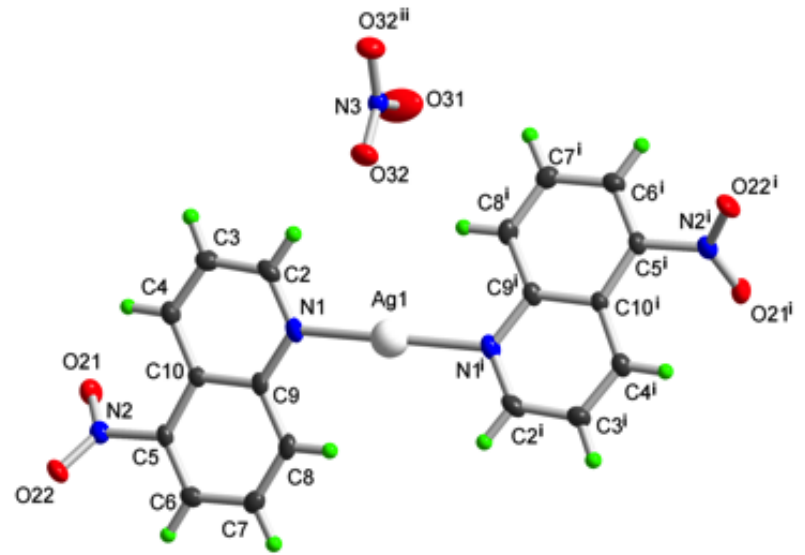

Figure 2: Numbering scheme for compound 1 with atomic displacement ellipsoids drawn at the 50\% probability level and the $\mathrm{Ag}(\mathrm{I})$ atom depicted as a sphere. For the symmetry codes, see Table 2.

Table 2: Bond lengths $[\AA]$ and angles $\left[{ }^{\circ}\right]$ for $\mathbf{1}$

\begin{tabular}{|c|c|}
\hline Ag1-N1 & $2.142(2)$ \\
\hline $\mathrm{Ag} 1-\mathrm{N} 1^{\mathrm{i}}$ & $2.142(2)$ \\
\hline $\mathrm{N} 1-\mathrm{Ag} 1-\mathrm{N} 1^{\mathrm{i}}$ & $172.25(13)$ \\
\hline
\end{tabular}

Symmetry code: (i): $-\mathrm{x}+2, \mathrm{y},-\mathrm{z}+5 / 2$

The packing diagram for compound $\mathbf{1}$ is shown in Figure 3. The relatively short distances between the 5-nitro groups of the adjacent molecules $\mathrm{O} 21 \ldots \mathrm{O} 21^{\mathrm{vii}}$ and $\mathrm{O} 22 \ldots \mathrm{O} 22^{\mathrm{viii}}$ are is 3.277(3) $\AA$ and 3.063(3) $\AA$, respectively (the sum of the van der Waals radii is $3.04 \AA)^{26}$ The symmetry codes $[($ vii $),-x+2, y,-z+3 / 2$; (viii), $-x+1, y,-z+3 / 2]$ may indicate a repulsion that has caused the nitro group to rotate around the $\mathrm{C}-\mathrm{N}$ bond and depart from the plane defined by their quinoline rings with distances of -0.796(4) $\AA$ and 0.770(4) $\AA$ for O21 and O22, respectively. 


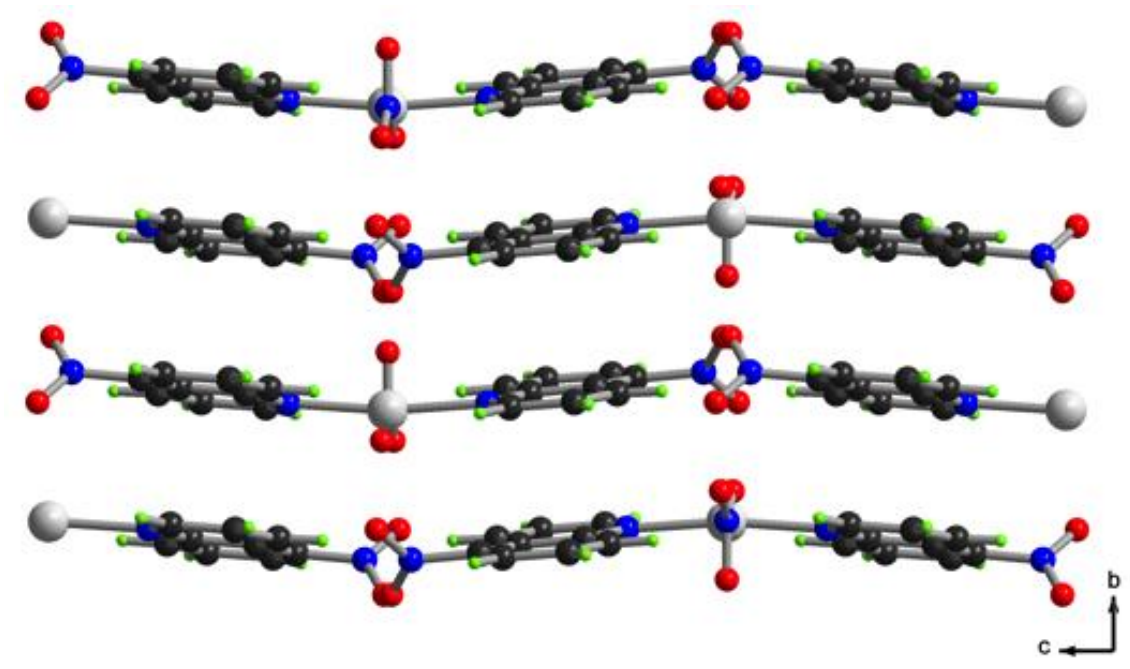

Figure 3: Packing diagram for compound $\mathbf{1}$ in the $(b, c)$ plane.

The attractive interactions between the $\operatorname{Ag}(\mathrm{I})$ ion and the nitro groups of the neighboring molecules should also be considered, with the distances for Ag...O21 ${ }^{\mathrm{iii}}, \mathrm{Ag} . . \mathrm{O} 21^{\mathrm{iv}}, \mathrm{Ag} \ldots \mathrm{O} 22^{\mathrm{v}}$, and $\mathrm{Ag} . . . \mathrm{O} 22^{\mathrm{vi}}$ being 2.993(2) $\AA$ and 2.951(2) $\AA$, respectively [symmetry codes: (iii), $-\mathrm{x}+2,-$ $\mathrm{y}+1,-\mathrm{z}+1 ;$ (iv), $\mathrm{x},-\mathrm{y}+1, \mathrm{z}+1 / 2 ;$ (v), $-\mathrm{x}+3 / 2,-\mathrm{y}+3 / 2,-\mathrm{z}+2 ;$ and (vi), $\mathrm{x}+1 / 2,-\mathrm{y}+3 / 2, \mathrm{z}+1 / 2]$. In addition, weak hydrogen bonds of the type C-H...O (C...O distances of 3.264(3) $\AA$ and 3.255(3) $\AA$, and $\mathrm{C}-\mathrm{H} . . . \mathrm{O}$ angles of $155^{\circ}$ and $137^{\circ}$ ) are present between the 5-nitro group and the quinoline moieties of the surrounding molecules connecting the cationic monomers $\left[\mathrm{Ag}(5-\mathrm{nqu})_{2}\right]^{+}$, giving rise to a $2 \mathrm{D}$ sheet structure in the $(\mathrm{a}, \mathrm{c})$ plane with the nitrate groups trapped between the planes. Although the nitrate anion forms weak hydrogen bonds, it does not form any strong interactions with the silver ion.

\section{$\left[\mathrm{Ag}(8-\mathrm{nqu})_{2}\right] \mathrm{NO}_{3} \cdot \mathrm{H}_{2} \mathrm{O}, 2$}

The crystal structure of compound $\mathbf{2}$ contains the crystallographically independent complexes a and $b$, the atom numbering schemes for which are shown in Figure 4, a and b. Both complexes include one cationic monomer $\left[\mathrm{Ag}(8-\mathrm{nqu})_{2}\right]^{+}$, one nitrate group, and one water molecule with different bond distances and angles (Table 3). Moving the nitro substituent from position 5 in compound $\mathbf{1}$ to position 8 in compound $\mathbf{2}$ does not influence the coordination geometry around the $\mathrm{Ag}(\mathrm{I})$ ion; a distorted linear geometry is still observed, although the interactions between the 
nitrate group and silver are stronger than those in $\mathbf{1}$ and the $\mathrm{Ag}-\mathrm{N}$ bond lengths are longer. In addition, there are interactions between the $\operatorname{Ag}(\mathrm{I})$ ion and both quinoline nitro groups and the water molecule (see Figure 4, a and b).

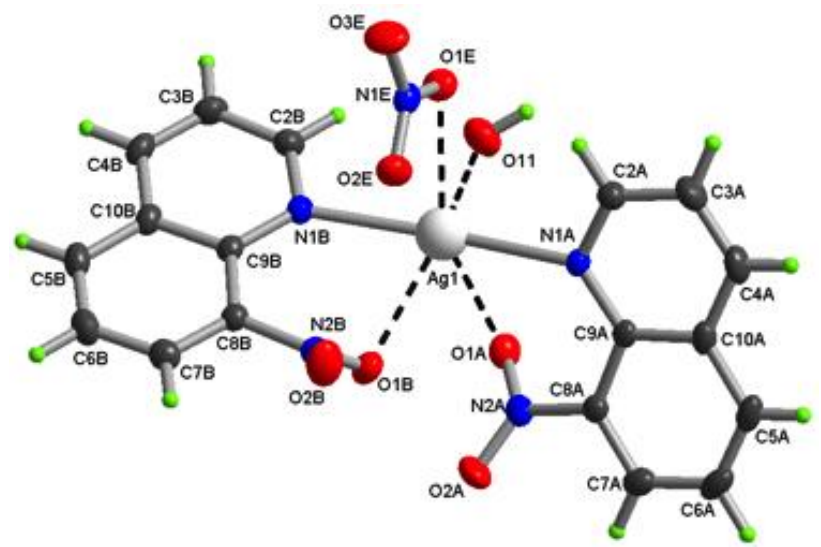

Figure 4a: Numbering scheme for compound 2, with atomic displacement ellipsoids drawn at the 50\% probability level, showing complex a. The $\operatorname{Ag}(\mathrm{I})$ atom is depicted as a sphere.

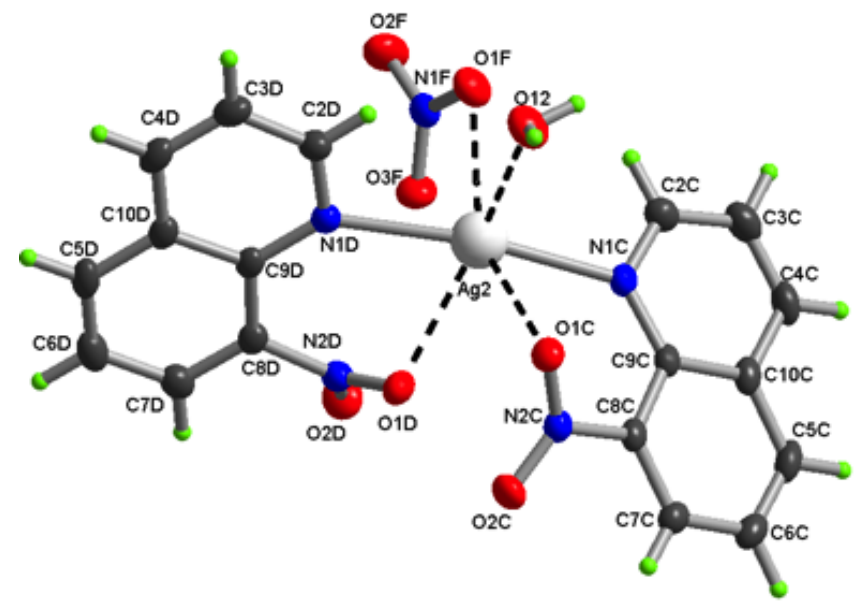

Figure 4b: Numbering scheme for compound 2, with atomic displacement ellipsoids drawn at the $50 \%$ probability level, showing complex b. The $\operatorname{Ag}(\mathrm{I})$ atom is depicted as a sphere. 
Table 3: Bond lengths $[\AA ̊ \cap]$ and angles $\left[{ }^{\circ}\right]$ of compound 2

\begin{tabular}{lr}
\hline Ag1-N1A & $2.303(2)$ \\
Ag1-N1B & $2.320(2)$ \\
Ag1-O11 & $2.529(2)$ \\
Ag1-O1B & $2.5955(19)$ \\
Ag2-N1C & $2.318(2)$ \\
Ag2-N1D & $2.336(2)$ \\
Ag2-O12 & $2.526(2)$ \\
Ag2-O1D & $2.5904(19)$ \\
N1A-Ag1-N1B & $169.40(7)$ \\
N1A-Ag1-O11 & $94.31(7)$ \\
N1B-Ag1-O11 & $94.98(7)$ \\
N1A-Ag1-O1B & $101.11(7)$ \\
N1B-Ag1-O1B & $73.04(6)$ \\
O11-Ag1-O1B & $149.37(7)$ \\
N1C-Ag2-N1D & $169.68(7)$ \\
N1C-Ag2-O12 & $94.51(8)$ \\
N1D-Ag2-O12 & $95.81(8)$ \\
N1C-Ag2-O1D & $98.59(7)$ \\
N1D-Ag2-O1D & $72.16(7)$ \\
O12-Ag2-O1D & $150.31(7)$ \\
\hline
\end{tabular}

In contrast to compounds $\mathbf{A}, \mathbf{B}$, and $\mathbf{1}$, the two aromatic rings in compound $\mathbf{2}$ are syn to each other in both complexes and the quinoline moieties in both complexes are more tilted than those in 1 due to steric hindrance by the two nitro groups; the dihedral angles are 57.67(4) ${ }^{\circ}$ and $59.17(4)^{\circ}$ for complexes a and $b$, respectively. This potent hindrance may account for the formation of longer Ag-N bond distances, i.e., 2.303(2)-2.336(2) $\AA$, and smaller N-Ag-N bond angles, i.e., $169.40(7)^{\circ}$ and $169.68(7)^{\circ}$, than in compounds $\mathbf{1}$ and $\mathbf{A}$. The packing arrangement is shown in Figure 5. The strong hydrogen bonds (Table 4) between the water molecules and nitrates form zigzag chains running in the $a$-direction (Figure 6). Significant $\pi-\pi$ stacking was also found, and this is discussed below. 


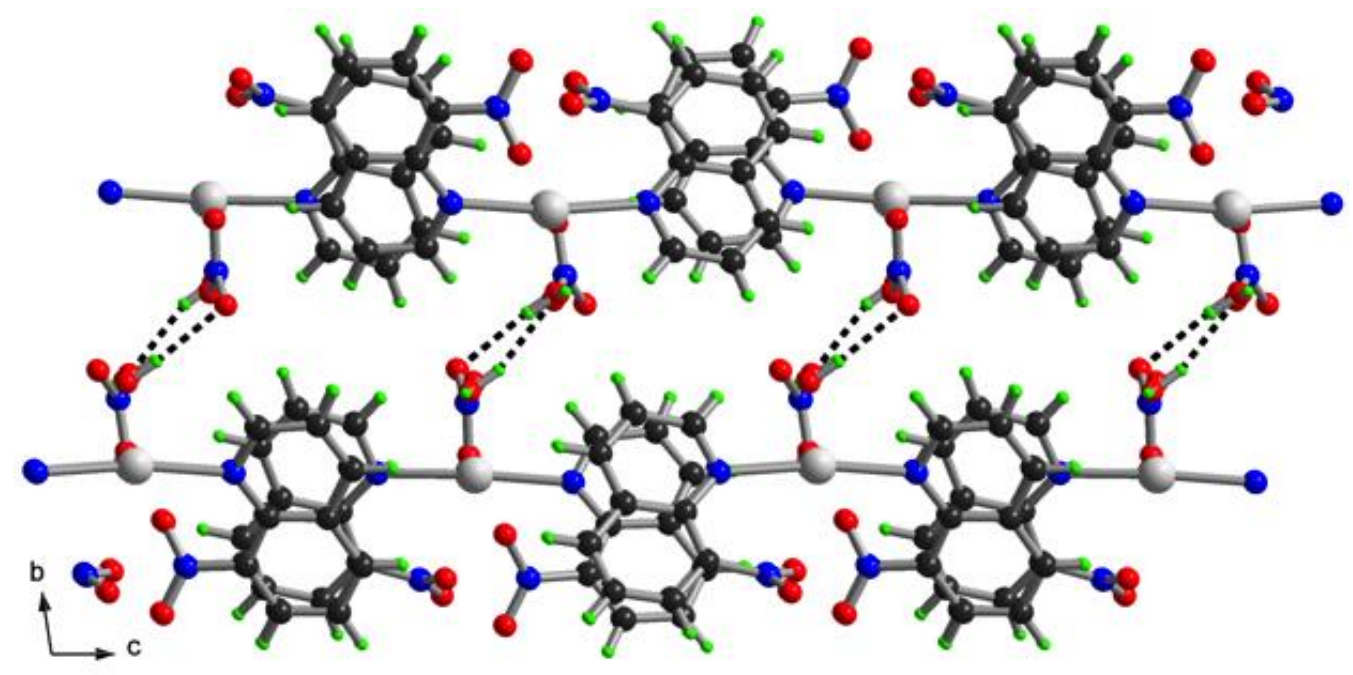

Figure 5: View of compound 2 along the $a$-axis showing the supramolecular 1D chains formed in the c direction due to strong $\pi-\pi$ stacking.

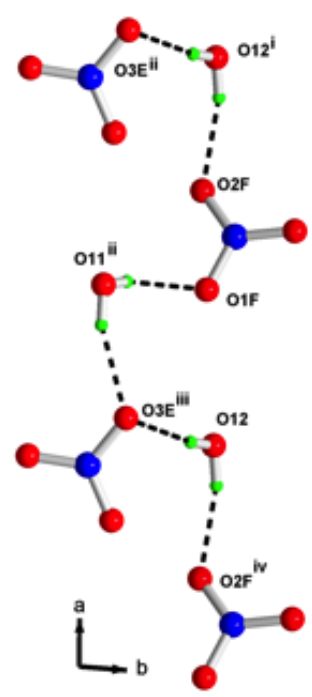

Figure 6: Hydrogen bonds between the nitrate groups and water molecules in compound 2. For the symmetry codes, see Table 4. 
Table 4: Characteristics of the hydrogen bonds for compound 2 [ $\AA$ and ${ }^{\circ}$ ]

\begin{tabular}{lllll}
\hline D-H...A & $\mathrm{d}(\mathrm{D}-\mathrm{H})$ & $\mathrm{d}(\mathrm{H} \ldots \mathrm{A})$ & $\mathrm{d}(\mathrm{D} \ldots \mathrm{A})$ & $<(\mathrm{DHA})$ \\
\hline $\mathrm{O} 11-\mathrm{H} 111 \ldots \mathrm{O} 3 \mathrm{E}^{\mathrm{i}}$ & $0.833(18)$ & $1.99(2)$ & $2.790(3)$ & $162(4)$ \\
$\mathrm{O} 11-\mathrm{H} 112 \ldots \mathrm{O} 1 \mathrm{~F}^{\mathrm{ii}}$ & $0.828(18)$ & $2.08(2)$ & $2.877(3)$ & $161(4)$ \\
$\mathrm{O} 12-\mathrm{H} 121 \ldots \mathrm{O} 3 \mathrm{E}^{\mathrm{iii}}$ & $0.841(19)$ & $2.14(2)$ & $2.976(3)$ & $170(4)$ \\
$\mathrm{O} 12-\mathrm{H} 122 \ldots \mathrm{O} 2 \mathrm{~F}^{\mathrm{iv}}$ & $0.840(19)$ & $2.00(2)$ & $2.823(3)$ & $167(4)$ \\
\hline
\end{tabular}

Symmetry codes: (i), x+1,y,z; (ii), -x+1,-y,-z+1; (iii), -x,-y,-z+1; (iv), x-1,y,z.

\section{$\left[\mathrm{Ag}(\mathrm{mnqu})\left(\mathrm{NO}_{3}\right)\right]_{n}, 3$}

The atom numbering scheme is shown in Figure 7, and selected bond distances and angles are listed in Table 5. The insertion of the bulky methoxy group at position 6 of the 8-nitroquinoline has significant impacts on the stoichiometry, yielding a 1:1 compound, and the structure. In this case, a distorted trigonal planar coordination geometry is formed around the $\operatorname{Ag}(\mathrm{I})$ ion via its coordination to one ligand and two nitrate groups. The Ag-N bond distances are longer than those found in $\mathbf{1}$, although they are comparable to those in $\mathbf{2}$, while the interaction between $\operatorname{Ag}(\mathrm{I})$ and the nitrate counter-ion is stronger than the corresponding interactions in $\mathbf{1}$ and $\mathbf{2}$. Both the Ag-N [2.2700(14) $\AA]$ and Ag-O [2.3467(16) $\AA$ and 2.5159(14) $\AA]$ bond distances are similar to those calculated for the trigonal planar compound $\mathbf{B}$. The difference between compounds $\mathbf{3}$ and $\mathbf{B}$ is that the $\operatorname{Ag}(\mathrm{I})$ ion is coordinated to one quinoline and two nitrate groups in $\mathbf{3}$, whereas it is coordinated to two quinolines and one nitrate group in $\mathbf{B}$. 


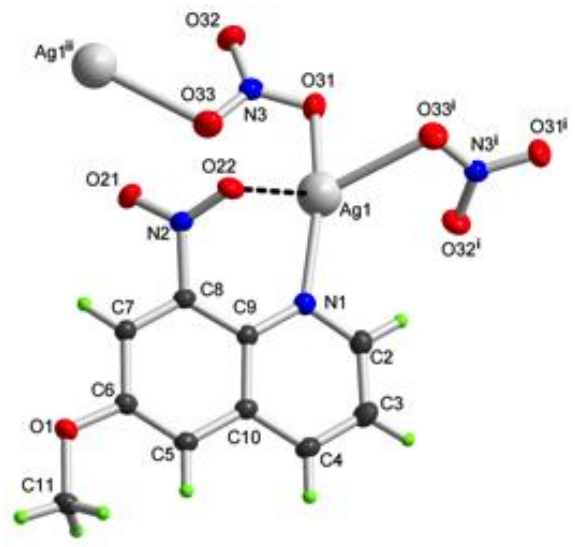

Figure 7: Numbering scheme for compound 3, with atomic displacement ellipsoids drawn at the 50\% probability level. For the symmetry codes, see Table 5 . The $\mathrm{Ag}(\mathrm{I})$ atoms are depicted as spheres.

Table 5: Bond lengths $[\AA ̊]$ and angles $\left[{ }^{\circ}\right]$ for compound $\mathbf{3}$

\begin{tabular}{lr}
$\mathrm{Ag} 1-\mathrm{N} 1$ & $2.2700(14)$ \\
$\mathrm{Ag} 1-\mathrm{O} 31$ & $2.3467(16)$ \\
$\mathrm{Ag} 1-\mathrm{O} 33^{\mathrm{i}}$ & $2.5159(14)$ \\
$\mathrm{N} 1-\mathrm{Ag} 1-\mathrm{O} 31$ & $155.56(5)$ \\
$\mathrm{N} 1-\mathrm{Ag} 1-\mathrm{O} 33^{\mathrm{i}}$ & $115.23(5)$ \\
$\mathrm{O}^{\mathrm{i}} 1-\mathrm{Ag} 1-\mathrm{O} 33^{\mathrm{i}}$ & $83.38(5)$ \\
\hline
\end{tabular}

Symmetry codes: (i), $\mathrm{x},-\mathrm{y}+1 / 2, \mathrm{z}-1 / 2 ;$ (ii), $\mathrm{x},-\mathrm{y}+1 / 2, \mathrm{z}+1 / 2$.

The nitrate groups are bridging, giving a 1D zigzag chain along the $c$-axis (Figure 8 ). Neither the silver ion nor the nitro group at $\mathrm{N} 2$ is co-planar with the quinoline, while the $\operatorname{Ag}(\mathrm{I})$ ions have only a weak $\mathrm{Ag} . . . \mathrm{O}_{(\mathrm{NO} 2)}$ interaction, with Ag-O22 being 2.646(13) $\AA$. The packing of compound 3 is shown in Figure 8. In addition, weak C-H...O hydrogen bonds are detected between the O$\mathrm{CH}_{3}$ group and the nitro group, with $\mathrm{H} . . . \mathrm{O}$ distances of 2.762-3.270 A. 


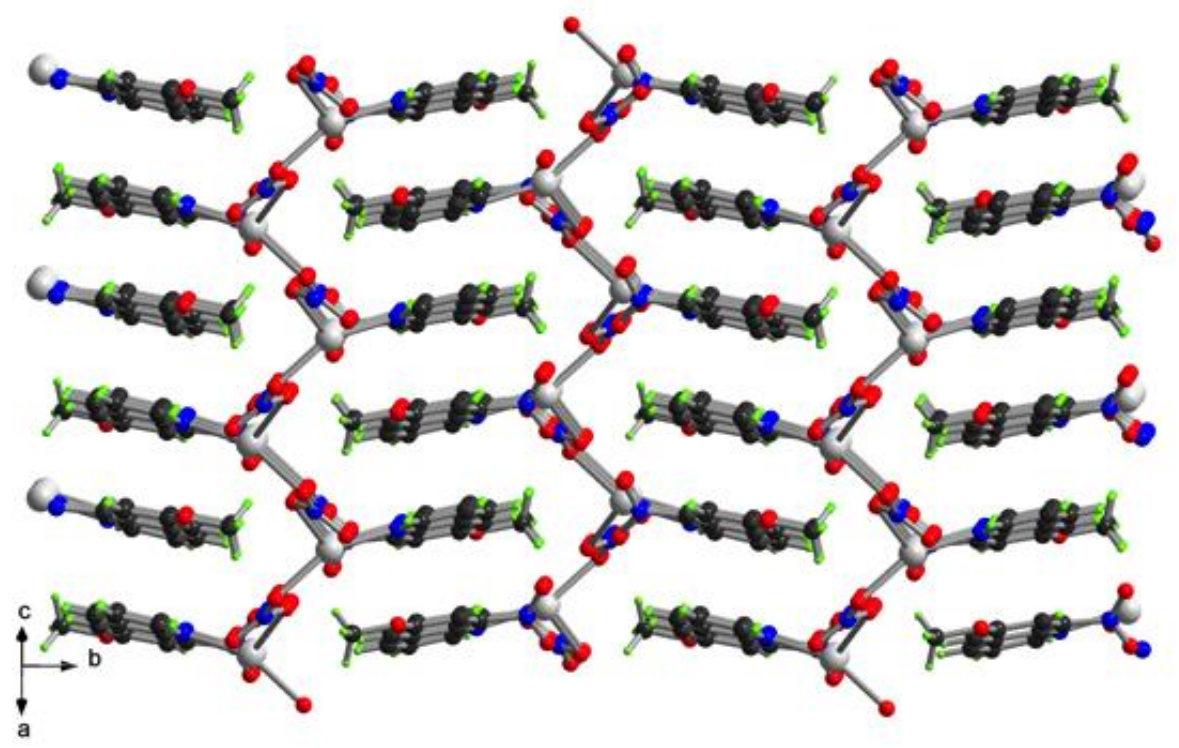

Figure 8: Packing diagram for compound $\mathbf{3}$ showing the $1 \mathrm{D}$ zigzag chain.

\section{$\left[\mathrm{Ag}(\mathrm{quc})\left(\mathrm{NO}_{3}\right)\right]_{n}, 4$}

The atom numbering scheme for compound $\mathbf{4}$ is shown in Figure 9. The structure of compound 4 is similar to that of compound $\mathbf{3}$, in that the $\mathrm{Ag}(\mathrm{I})$ ion coordinates one 3-quinolinecarbonitrile and two nitrate groups, forming a distorted trigonal planar coordination geometry. The Ag-N and Ag$\mathrm{O}$ bond distances are shorter than those of compounds $\mathbf{3}$ and $\mathbf{B}$; selected bond distances and bond angles are presented in Table 6 . The presence of a $\mathrm{C} \equiv \mathrm{N}$ group at position 3 of the quinoline is less hindering than an $\mathrm{NO}_{2}$ at position 8 in compounds $\mathbf{2}$ and $\mathbf{3}$, with the consequence that a lessdistorted geometry is formed. There are no interactions between the $\mathrm{C} \equiv \mathrm{N}$ substituents and the $\mathrm{Ag}(\mathrm{I})$ ions. Instead, the $\mathrm{C} \equiv \mathrm{N}$ groups form weak hydrogen bonds. 


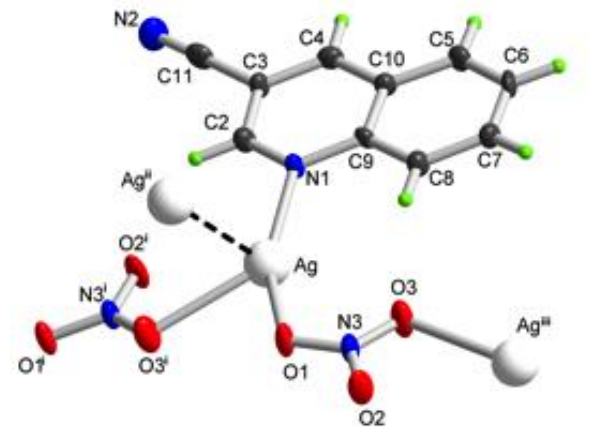

Figure 9: Numbering scheme for compound 4, with atomic displacement ellipsoids drawn at the 50\% probability level. The Ag(I) atoms are depicted as spheres. For the symmetry codes, see Table 6.

Table 6: Bond lengths $[\AA]$ and angles $\left[{ }^{\circ}\right]$ for compound 4

\begin{tabular}{lr}
$\mathrm{Ag}-\mathrm{N} 1$ & $2.224(5)$ \\
$\mathrm{Ag}-\mathrm{O} 1$ & $2.261(4)$ \\
$\mathrm{Ag}-\mathrm{O} 3^{\mathrm{i}}$ & $2.536(5)$ \\
$\mathrm{Ag}^{\mathrm{Ag}}{ }^{\mathrm{ii}}$ & $3.1230(12)$ \\
$\mathrm{O} 3-\mathrm{Ag}^{\mathrm{iii}}$ & $2.536(5)$ \\
$\mathrm{N} 1-\mathrm{Ag}-\mathrm{O} 1$ & $153.51(18)$ \\
$\mathrm{N} 1-\mathrm{Ag}-\mathrm{O} 3^{\mathrm{i}}$ & $130.08(16)$ \\
$\mathrm{O} 1-\mathrm{Ag}-\mathrm{O} 3^{\mathrm{i}}$ & $74.93(15)$ \\
$\mathrm{N} 1-\mathrm{Ag}-\mathrm{Ag}^{\mathrm{ii}}$ & $105.26(13)$ \\
$\mathrm{O} 1-\mathrm{Ag}-\mathrm{Ag}^{\mathrm{ii}}$ & $73.49(11)$ \\
$\mathrm{O}^{\mathrm{i}}-\mathrm{Ag}-\mathrm{Ag}^{\mathrm{ii}}$ & $68.42(11)$ \\
\hline
\end{tabular}

Symmetry codes: (i), -x,y-1/2,-z+1/2; (ii), -x,-y+1,-z+1; (iii), -x,y+1/2,-z+1/2.

The bridging nitrate groups form a zigzag chain in the $b$ direction. Hydrogen bonds of the type C-H...O and C-H...N (Table 7) connect these planar zigzag chains to form a 2D sheet in the $a, b$ plane (see Figure 10). 


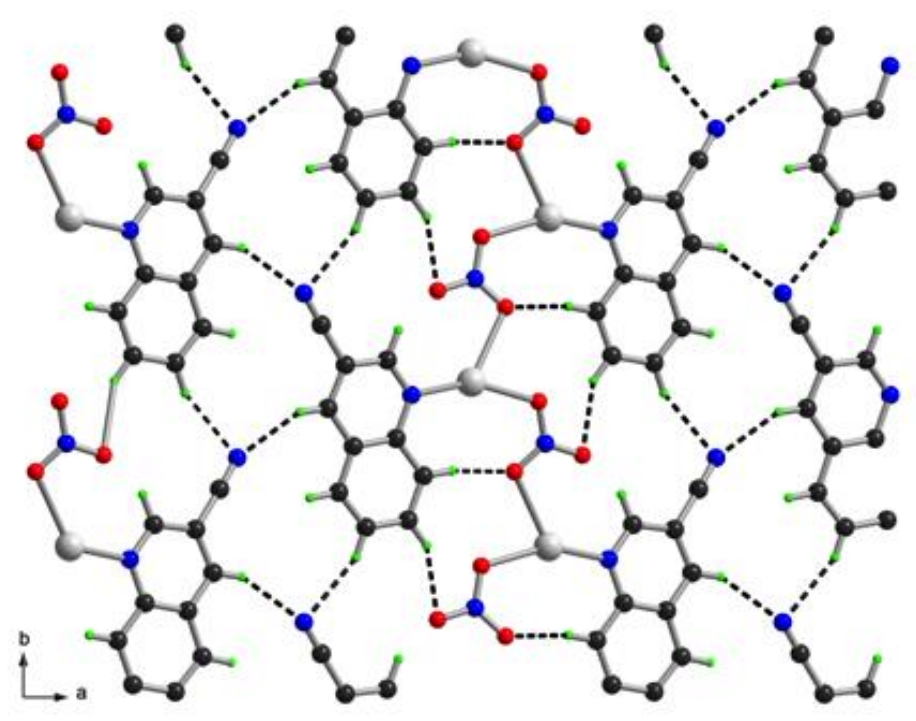

Figure 10: 2D sheet of compound 4 is formed via C-H...O and C-H...N hydrogen bonds (broken lines) in the $(a, b)$ plane.

Table 7 : Hydrogen bonds for compound 4 [^ and $\left.{ }^{\circ}\right]$

\begin{tabular}{lllll}
\hline D-H...A & $\mathrm{d}(\mathrm{D}-\mathrm{H})$ & $\mathrm{d}(\mathrm{H} \ldots \mathrm{A})$ & $\mathrm{d}(\mathrm{D} \ldots \mathrm{A})$ & $<(\mathrm{DHA})$ \\
\hline $\mathrm{C} 2-\mathrm{H} 2 \ldots \mathrm{O} 2^{\mathrm{i}}$ & 0.95 & 2.34 & $3.112(8)$ & 138 \\
$\mathrm{C} 4-\mathrm{H} 4 \ldots \mathrm{N} 2^{\mathrm{iv}}$ & 0.95 & 2.60 & $3.481(8)$ & 155 \\
$\mathrm{C} 7-\mathrm{H} 7 \ldots \mathrm{O} 2^{\mathrm{iii}}$ & 0.95 & 2.55 & $3.410(8)$ & 150 \\
$\mathrm{C} 8-\mathrm{H} 8 \ldots \mathrm{O} 3$ & 0.95 & 2.53 & $3.442(8)$ & 161 \\
\hline
\end{tabular}

Symmetry codes: (i), -x,y-1/2,-z+1/2; (ii), -x,-y+1,-z+1; (iii), -x,y+1/2,-z+1/2; (iv), -x-1,y+1/2,-z+3/2.

In addition, an Ag...Ag interaction, 3.1230(12) $\AA$, between the sheets extends the structure to form a complicated 3D network.

\section{$\left[\mathrm{Ag}(\mathrm{quc})_{2}\right] \mathrm{NO}_{3}, 5$}

The atom numbering scheme for compound $\mathbf{5}$ is shown in Figure 11, and selected bond distances and bond angles are listed in Table 8 . The $\mathrm{Ag}(\mathrm{I})$ ion is coordinated to two ligands via the nitrogen atom of the quinoline rings, to form a distorted linear geometry. Silver, N3 and O2 lie on a twofold axis. The Ag-N bond distances are longer than those reported for $\mathbf{4}$ and much longer than those of the monomeric compounds $\mathbf{1}$ and $\mathbf{A}$, owing to the presence of the two bulky ligands in syn orientation to each other. There is a weak interaction between the $\operatorname{Ag}(\mathrm{I})$ ion and the nitrate group; the Ag-O1 distance is 2.635(3) $\AA$, which is at the extreme limit for influencing the $\mathrm{N}-\mathrm{Ag}$ - 
$\mathrm{N}$ angles, which as a consequence is close to linear at $163.62(13)^{\circ}$. The quinoline moieties in 5 are not co-planar, and the molecules are arranged in parallel planes whereby the $\mathrm{Ag}(\mathrm{I}), \mathrm{N} 3$, and $\mathrm{O} 2$ of the nitrate groups are located between these planes.

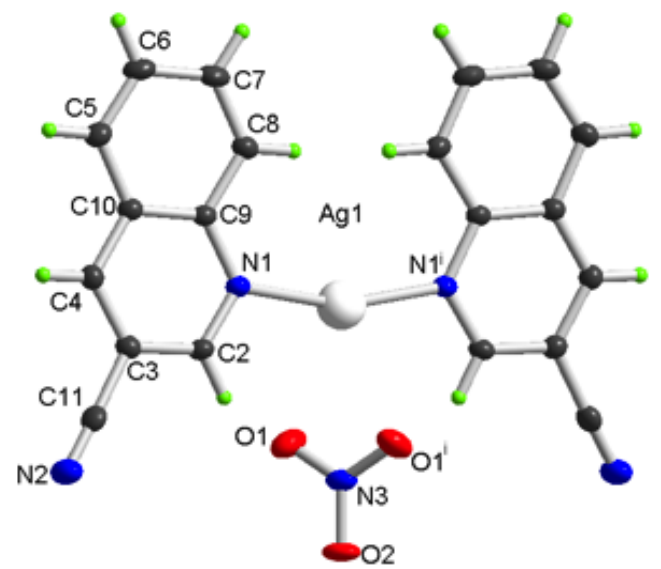

Figure 11: Numbering scheme for compound 5, with atomic displacement ellipsoids drawn at the 50\% probability level. The $\mathrm{Ag}(\mathrm{I})$ atom is depicted as a sphere. For the symmetry code, see Table 8.

Table 8: Bond lengths $[\AA]$ and angles $\left[{ }^{\circ}\right]$ for compound $\mathbf{5}$

\begin{tabular}{lr}
\hline Ag1-N1 & $2.247(3)$ \\
Ag1-N1 ${ }^{i}$ & $2.248(3)$ \\
N1-Ag1-N1 & $163.62(13)$ \\
\hline
\end{tabular}

Symmetry code: (i), $-\mathrm{x}, \mathrm{y},-\mathrm{z}+1 / 2$.

Hydrogen bonds of the type $\mathrm{C}-\mathrm{H} \ldots \mathrm{O}$ and $\mathrm{C}-\mathrm{H} \ldots \mathrm{N}$ (Table 9) connect the cationic monomers $\left[\mathrm{Ag}(\mathrm{quc})_{2}\right]^{+}$via the nitrate groups to form 1D strands of molecules in the $(a$,

b) plane (Figure 12). 


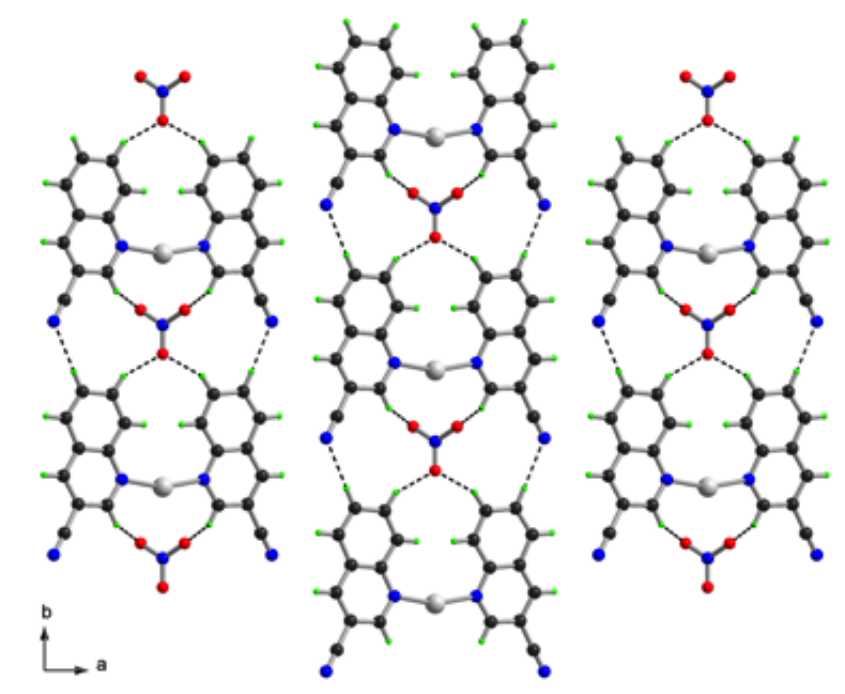

Figure 12: Packing diagram for compound 5 showing the strands of molecules formed in the $(a, b)$ plane via hydrogen bonds.

Table 9: Hydrogen bonds for compound $\mathbf{5}\left[\AA\right.$ and $\left.^{\circ}\right]$

\begin{tabular}{lllll}
\hline D-H...A & $\mathrm{d}(\mathrm{D}-\mathrm{H})$ & $\mathrm{d}(\mathrm{H} \ldots \mathrm{A})$ & $\mathrm{d}(\mathrm{D} \ldots \mathrm{A})$ & $<(\mathrm{DHA})$ \\
\hline $\mathrm{C} 2-\mathrm{H} 2 \ldots \mathrm{O}^{\mathrm{i}}$ & 0.93 & 2.54 & $3.188(4)$ & 127 \\
$\mathrm{C} 6-\mathrm{H} 6 \ldots \mathrm{N} 2^{\mathrm{ii}}$ & 0.93 & 2.55 & $3.461(4)$ & 166 \\
$\mathrm{C} 7-\mathrm{H} 7 \ldots \mathrm{O} 2^{\mathrm{ii}}$ & 0.93 & 2.36 & $3.177(4)$ & 146 \\
\hline
\end{tabular}

Symmetry codes: (i), -x,y,-z+1/2; (ii), x,y+1,z.

\section{$\left[\mathrm{Ag}(\mathrm{quCOOH})_{2}\right] \mathrm{NO}_{3}, 6$}

The atom numbering scheme for compound $\mathbf{6}$ is shown in Figure 13, and the bond distances and bond angles are listed in Table 10. The $\operatorname{Ag}(\mathrm{I})$ ion has a distorted linear geometry due to its coordination of two 6-quinoline carboxylic acid ligands via their nitrogen atoms on the quinoline rings, while the carboxylic acid group is not coordinated to the $\mathrm{Ag}(\mathrm{I})$ ion. Octahedral carboxylate compounds are normally formed when this ligand reacts with $\mathrm{M}^{2+}$ metal ions $\left(\mathrm{M}^{2+}=\mathrm{Fe}, \mathrm{Co}, \mathrm{Ni}\right.$ and $\mathrm{Zn}) .{ }^{15}$ The structure of monomeric compound $\mathbf{6}$ is very similar to those of compounds $\mathbf{1}$ and A, although the substituents are different: $\mathrm{NO}_{2}$ in $\mathbf{1}$ and $\mathrm{COOH}$ in $\mathbf{6}$. Their $\mathrm{Ag}-\mathrm{N}$ bond distances and N-Ag-N bond angles of these compounds are very similar. The interaction between the $\operatorname{Ag}(\mathrm{I})$ ion and the nitrate group in $\mathbf{6}$ is very weak, and the shortest Ag...O distance is 2.7836(17) $\AA$. The two phenyl rings are oriented anti to each other, as in compounds $\mathbf{A}, \mathbf{B}$ and $\mathbf{1 .}$ 


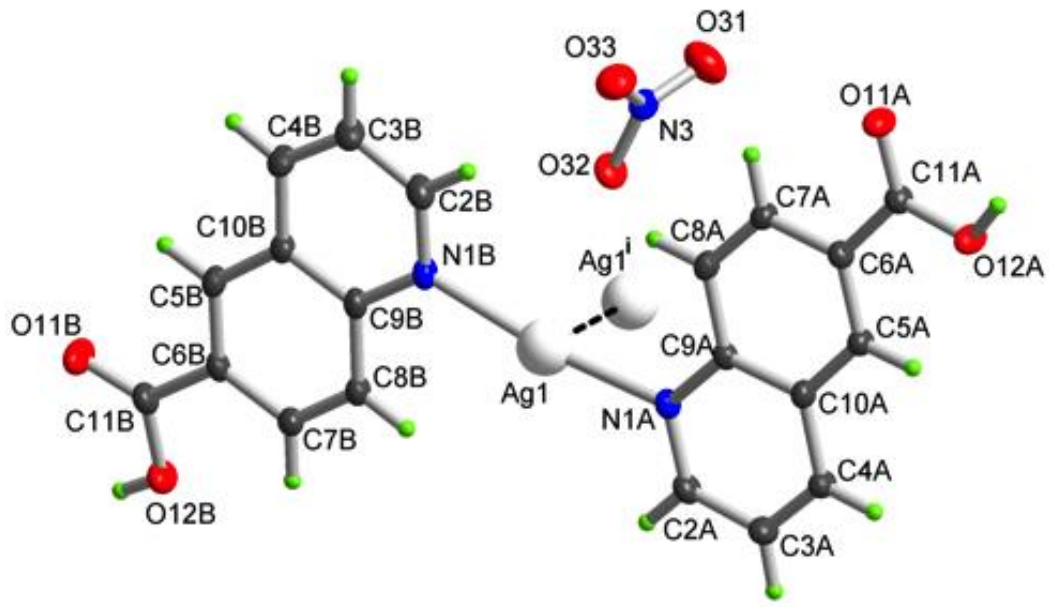

Figure 13: Numbering scheme for compound 6, with atomic displacement ellipsoids drawn at the 50\% probability level. Ag(I) atoms are depicted as spheres. For the symmetry code, see Table 10.

Table 10: Bond lengths $[\AA]$ and angles $\left[{ }^{\circ}\right]$ for compound 6

\begin{tabular}{lr}
\hline Ag1-N1B & $2.1597(15)$ \\
Ag1-N1A & $2.1680(15)$ \\
Ag1-Ag1 & $3.2388(4)$ \\
N1B-Ag1-N1A & $168.15(5)$ \\
N1B-Ag1-Ag1 ${ }^{\mathrm{i}}$ & $94.49(4)$ \\
N1A-Ag1-Ag1 & $92.04(4)$ \\
\hline
\end{tabular}

Symmetry code: (i), $-\mathrm{x}+1,-\mathrm{y}+2,-\mathrm{z}+1$.

Strong hydrogen bonds of the type O-H... (listed in Table 11) are formed between the $-\mathrm{COOH}$ groups, forming classical carboxylic acid dimeric units, and between the $-\mathrm{OH}$ group and one of the nitrate oxygen atoms in the structure. $\mathrm{Ag}$...Ag interactions occur between the stacked molecules, Ag1 ...Ag1 $1^{i} 3.2388(4) \AA$. The packing of compound 6 is shown in Figure 14.

Table 11: Hydrogen bonds for compound 6 [ and $^{\circ}$ ]

\begin{tabular}{lllll}
\hline D-H...A & $\mathrm{d}(\mathrm{D}-\mathrm{H})$ & $\mathrm{d}(\mathrm{H} \ldots \mathrm{A})$ & $\mathrm{d}(\mathrm{D} \ldots \mathrm{A})$ & $<(\mathrm{DHA})$ \\
\hline O12A-H12A...O11A & 0.84 & 1.81 & $2.6426(18)$ & 173 \\
O12B-H12B...O31 & 0.84 & 1.87 & $2.680(2)$ & 163 \\
\hline
\end{tabular}

Symmetry codes: (ii), $-\mathrm{x}+3,-\mathrm{y}+2,-\mathrm{z}$; (iii), $-\mathrm{x},-\mathrm{y}+2,-\mathrm{z}+2$. 


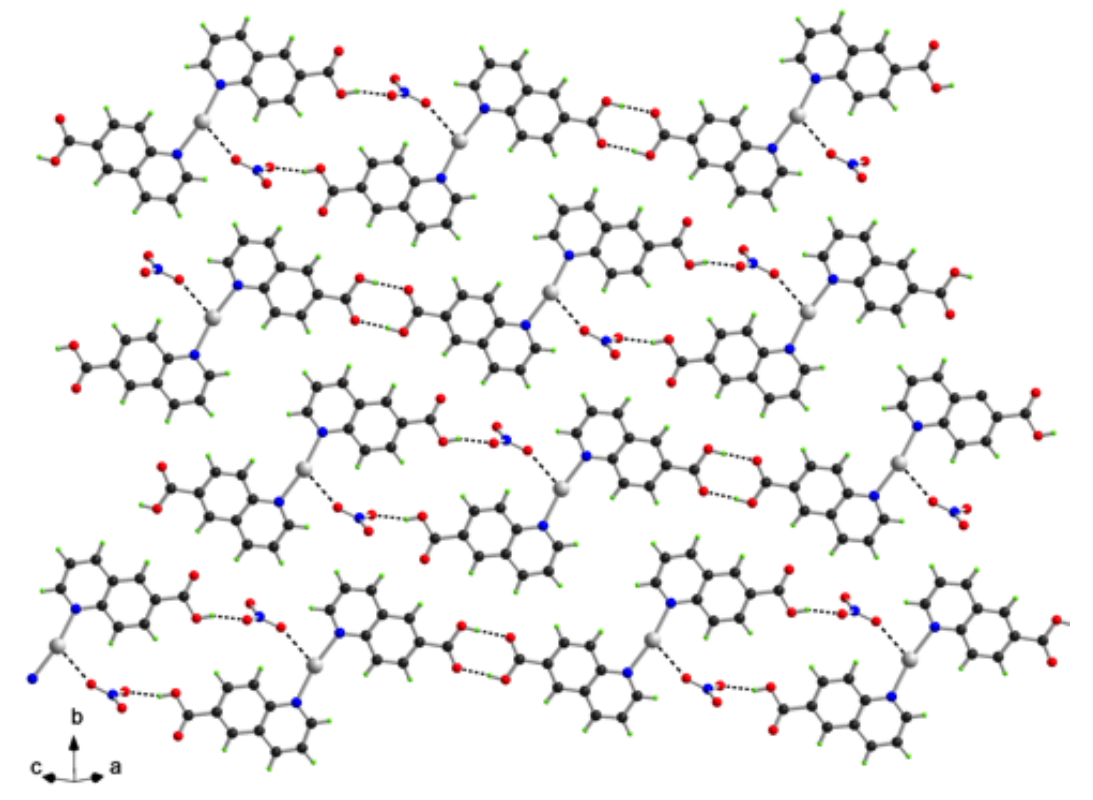

Figure 14: Packing diagram for compound 6. Hydrogen bonds are depicted as broken lines.

\section{Coordinating or non-coordinating nitrate}

Nitro-quinoline compounds (1, 2 and 3) Since no strong hydrogen bond donors have been found for these compounds (the $\mathrm{NO}_{2}$ groups are slightly hydrophilic but can only accept hydrogen bonds), the nitrate counter-ions should, in the absence of water molecules, be assembled around the $\mathrm{Ag}(\mathrm{I})$ ions. In the case of compound $\mathbf{1},\left[\mathrm{Ag}(5-\mathrm{nqu})_{2}\right] \mathrm{NO}_{3}$, the $\mathrm{Ag}(\mathrm{I})$ centers are surrounded by the nitro groups of the adjacent ligands and no direct interaction with the nitrate groups is observed; the Ag...O distance is 3.778(2) $\AA$. This is contrary to what our theory would predict, so we need to scrutinize in greater detail the environment around the nitrate. The reason for the discrepancy becomes clear in Figure 15, where it is shown how the polar groups in the structure have been assembled around the nitrate ion, revealing a third way to "deal with" the charged and "hard" nitrate ion. 


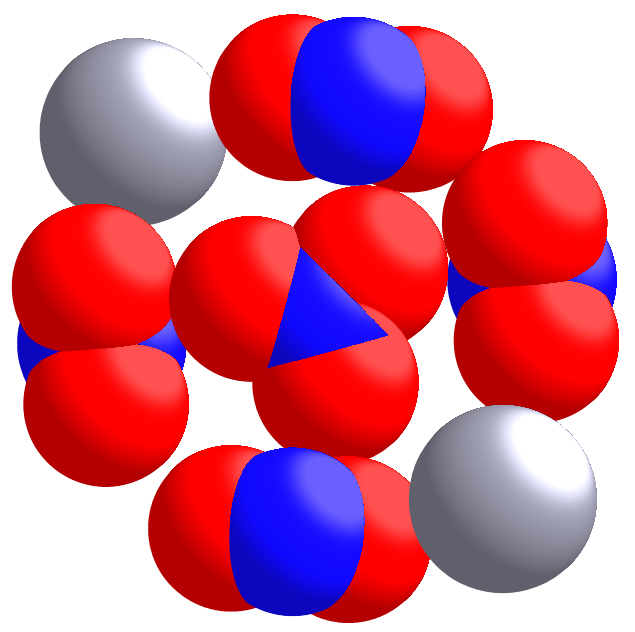

Figure 15: Nitrate environment in $\mathbf{1}$ showing a space-filling model of the nitrate and the surrounding $\mathrm{NO}_{2}$ groups and silver ions in the $(a, b)$ plane.

In $\left[\mathrm{Ag}(8-\mathrm{nqu})_{2}\right] \mathrm{NO}_{3} \cdot \mathrm{H}_{2} \mathrm{O}$ 2, the nitrate groups are hydrogen-bonded to water molecules. In addition, the presence of the nitro substituents at position 8 and oriented syn to each other gives more space for both water and nitrate to interact with the $\mathrm{Ag}(\mathrm{I})$ centers; the $\mathrm{Ag}$... O distances are 2.529(2), 2.527(2), 2.6216(18), and 2.6242(19) $\AA$ for water and nitrate, respectively. The presence of the hydrophobic methoxy group at position 6 in compound $\mathbf{3},\left[\mathrm{Ag}(\mathrm{mnqu})\left(\mathrm{NO}_{3}\right)\right]_{n}$, ensures that the nitrate group is coordinated to the $\mathrm{Ag}(\mathrm{I})$ ions with $\mu-\mathrm{O}, \mathrm{O}^{\prime}$ bridging mode, so as to form a 1D chain of molecules.

A search of the CSD database ${ }^{14}$ for similar nitrobenzene compounds revealed that the torsion angles between the nitro groups and the rings are localized around $0^{\circ}$, which means that they are coplanar with their rings. In contrast, the nitro substituents for compounds $\mathbf{1}, \mathbf{2}$, and $\mathbf{3}$ are not coplanar with the quinoline rings. (Torsion angles: compound 1, $-134^{\circ}, 45^{\circ}$, and $-136^{\circ}$; compound $2,38^{\circ}, 40^{\circ}, 44^{\circ}, 46^{\circ}, 130^{\circ}, 132^{\circ}, 144^{\circ}, 150^{\circ},-33^{\circ},-34^{\circ},-48^{\circ},-50^{\circ},-134^{\circ},-137^{\circ},-$ $138^{\circ}$, and $-144^{\circ}$; compound $3,133^{\circ}, 137^{\circ},-44^{\circ}$, and $-46^{\circ}$ ).

Carbonitrile-quinoline and carboxylic acid-quinoline compounds $(\mathbf{4}, \mathbf{5}$, and 6$)$ The $1 \mathrm{D}$ coordination polymer $\mathbf{4},\left[\mathrm{Ag}(\mathrm{quc})\left(\mathrm{NO}_{3}\right)\right]_{n}$, with the $\mu-\mathrm{O}, \mathrm{O}^{\prime}$ bridging nitrate, was obtained as a minor product during the synthesis, and its structure is in good agreement with the notion of the absence of hydrogen bond donors. However, in compound $\mathbf{5}$, there is no silver-nitrate interaction, 
which we ascribe to the multiple weak hydrogen bonds shown in Figure 12, forming a distinct and beautiful pattern. While carboxylic acid substituents are hydrogen bond donors to nitrate, they also have a very strong tendency to form hydrogen-bonded dimers. In compound $\mathbf{6}$, $\left[\mathrm{Ag}(\mathrm{quCOOH})_{2}\right] \mathrm{NO}_{3}$, both motifs are found, and there are only very weak Ag-O interactions at

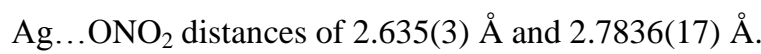

\section{Intermolecular interactions and analysis of Hirshfeld surfaces}

The quinoline ligands have two fused aromatic rings; the pyridine and the benzene. Therefore, three distinct interactions can occur between the ligands: 1) benzene-benzene; 2) benzene-pyridine; and 3) pyridine-pyridine stacking. The strongest possible $\pi-\pi$ stacking interactions for compounds 1-6 are listed in Table 12 and compared to compounds $\mathbf{A}$ and $\mathbf{B}$. Hirshfeld $d_{\text {norm }}$ maps and curvedness maps for compounds 1-6 are shown in Figures 16 and 17 , respectively.

Table 12: Most significant $\pi-\pi$ stacking interactions for compounds 1-6, as compared with compounds $\mathbf{A}$ and $\mathbf{B}$.

\begin{tabular}{|l|c|c|c|c|}
\hline \multicolumn{1}{|c|}{ Compound } & $\begin{array}{c}\pi_{\text {benzene }}-\pi_{\text {benzene }} \\
\text { centroid-centroid } \\
\text { distance }(\AA)\end{array}$ & $\begin{array}{c}\pi_{\text {benzene }}-\pi_{\text {pyridine }} \\
\text { centroid-centroid } \\
\text { distance }(\AA)\end{array}$ & $\begin{array}{c}\pi_{\text {pyridine }}-\pi_{\text {pyridine }} \\
\text { centroid-centroid } \\
\text { distance }(\AA)\end{array}$ & $\begin{array}{c}\text { Angle } \beta\left(^{\circ}\right) \text { for shortest } \\
\text { centroid-centroid } \\
\text { distances }\end{array}$ \\
\hline$\left[\mathrm{Ag}(\mathrm{qu})_{2}\right] \mathrm{ClO}_{4}{ }^{24} \mathbf{A}$ & $3.752(5)$ & $3.652(5)$ & $4.907(6)$ & 23 \\
\hline$\left[\mathrm{Ag}{ }_{2}(\mathrm{qu})_{4}\left(\mathrm{NO}_{3}\right)_{2}\right]^{24} \mathbf{B}$ & $3.66(3)$ & $3.58(3)$ & $3.81(2)$ & 16 \\
\hline$\left[\mathrm{Ag}(5-\mathrm{nqu})_{2}\right] \mathrm{NO}_{3} \mathbf{1}$ & $3.5231(15)$ & $3.9709(16)$ & $3.5234(15)$ & 12 \\
\hline$\left[\mathrm{Ag}(8-\mathrm{nqu})_{2}\right] \mathrm{NO}_{3} \cdot \mathrm{H}_{2} \mathrm{O} \mathbf{2}$ & $3.7304(14)$ & $3.5583(14)$ & $3.6290(15)$ & 21 \\
\hline$\left[\mathrm{Ag}(\mathrm{mnqu})\left(\mathrm{NO}_{3}\right)_{2}\right]_{n} \mathbf{3}$ & $3.5968(10)$ & $3.6786(11)$ & $3.8305(11)$ & 28 \\
\hline$\left[\mathrm{Ag}(\mathrm{quc})\left(\mathrm{NO}_{3}\right)_{2}\right]_{n} \mathbf{4}$ & $4.276(3)$ & $3.573(3)$ & $4.552(3)$ & 21 \\
\hline$\left[\mathrm{Ag}(\mathrm{quc})_{2}\right] \mathrm{NO}_{3} \mathbf{5}$ & $4.0796(18)$ & $3.7704(18)$ & $5.0162(18)$ & \\
\hline$\left[\mathrm{Ag}(\mathrm{quCOOH})_{2}\right] \mathrm{NO}_{3} \mathbf{6}$ & $3.6029(11)$ & $4.1188(11)$ & $3.6850(12)$ & \\
\hline
\end{tabular}




\begin{tabular}{|l|l|l|l|l|}
\hline Average & 3.777 & 3.738 & 4.119 & \\
\hline
\end{tabular}

For almost all the compounds, the three interactions are relatively strong, with the shortest average interactions being found for compound $\mathbf{2}$, which may account for the formation of the 1D chain of molecules, as shown in Figure 5 . On average, the $\pi_{\text {pyridine }}-\pi_{\text {pyridine }}$ interactions are the weakest, which may be related to the steric hindrance from the silver center.

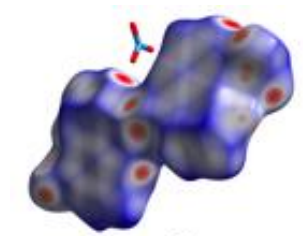

(1)

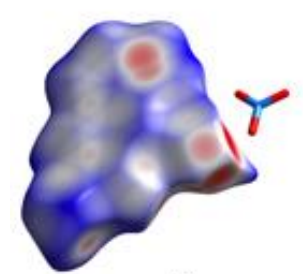

(4)

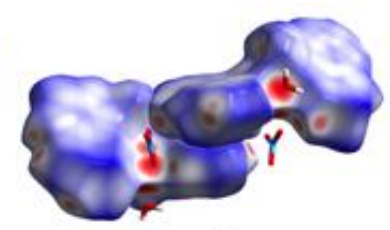

(2)

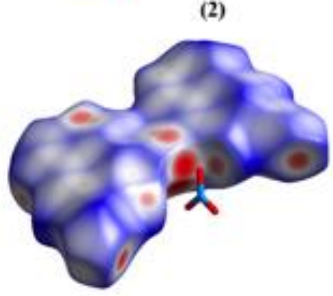

(5)

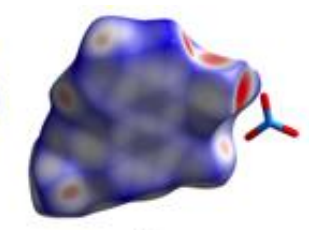

(3)

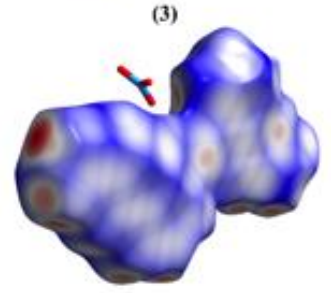

(6)

Figure 16: Hirshfeld $d_{\text {norm }}$ maps for compounds 1-6.

The Hirshfeld $d_{\text {norm }}$ maps for compounds 1-6 (Figure 16) show strong interactions around the $\mathrm{Ag}(\mathrm{I})$ ions (red regions in Figure 16) due to its coordination to the ligands, interactions with nitrate counter ions, interactions with neighboring nitro groups (compounds 1 and 2), and short Ag...Ag interactions (compounds $\mathbf{4}$ and $\mathbf{6}$ ). Possible hydrogen bonds for compounds 4-6 are also represented as red regions in Figure 16. The curvedness map (Figure 17) shows flattened surfaces for all the compounds, indicating $\pi-\pi$ stacking intermolecular interactions, in agreement with the data presented in Table 12 . 


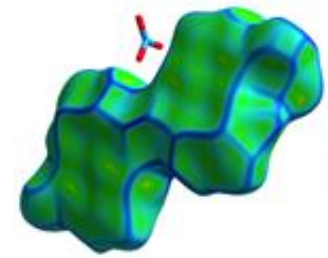

(1)

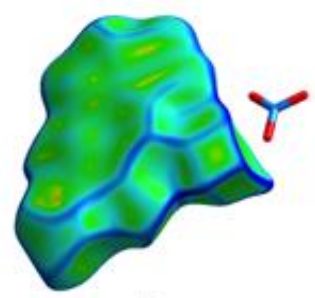

(4)

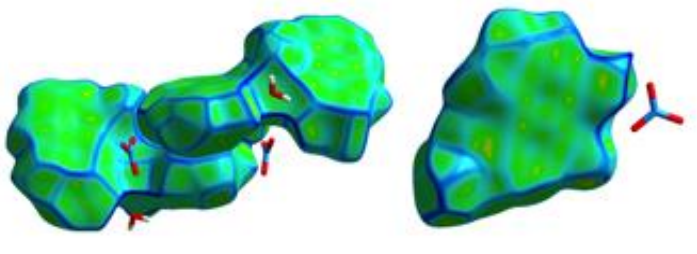

(2)

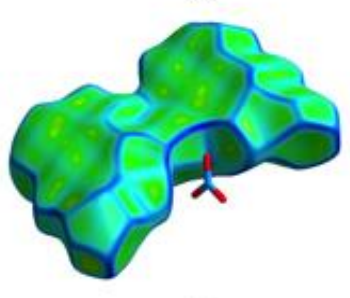

(5)

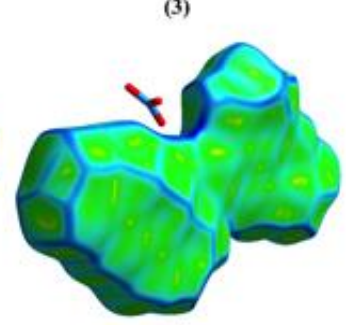

(6)

Figure 17: Hirshfeld curvedness maps for compounds 1-6.

\section{Antibacterial activities}

The antibacterial activities of compounds 1-2 and $\mathbf{6}$ were screened against 15 different clinically isolated pathogens. The MICs of the compounds were compared to the MICs of silver sulfadiazine (SS) in DMSO (Table 13).

Table 13: Anti-bacterial activities of compounds 1-2 and $\mathbf{6}$ in terms of MIC $(\mu \mathrm{g} / \mathrm{ml})$ values, compared to silversulfadiazine $(\mathbf{S S})$

\begin{tabular}{|c|c|c|c|c|}
\hline \multirow{2}{*}{ Test organism } & \multicolumn{4}{|c|}{ Compound } \\
\cline { 2 - 5 } & $\mathbf{1}$ & $\mathbf{2}$ & $\mathbf{6}$ & SS \\
\cline { 2 - 5 } & \multicolumn{4}{|c|}{ MIC $(\boldsymbol{\mu g} / \mathbf{m l})$} \\
\hline Alloiococcus otitidis & 128 & $\mathbf{8}$ & 16 & 8 \\
\hline Bacillus cereus & 64 & $\mathbf{8}$ & $\mathbf{8}$ & $\mathbf{8}$ \\
\hline Bacillus megaterium & $>256$ & 16 & $\mathbf{8}$ & 16 \\
\hline Bacillus sp. & 32 & 32 & 64 & $\mathbf{1 6}$ \\
\hline Micrococcus luteus & $\mathbf{8}$ & $\mathbf{8}$ & $\mathbf{8}$ & $\mathbf{8}$ \\
\hline Staphylococcus aureus & $>256$ & 32 & 32 & $\mathbf{1 6}$ \\
\hline Stomatococcus mucilaginosus & 16 & 32 & 16 & $\mathbf{8}$ \\
\hline Capnocytophaga cynodegmi & 128 & 32 & 32 & $\mathbf{1 6}$ \\
\hline Corynebacterium urealyticum & 64 & 8 & $\mathbf{4}$ & 16 \\
\hline Corynebacterium minutissinum & $>256$ & 16 & $>256$ & $\mathbf{8}$ \\
\hline Escherichia coli & 64 & 32 & $>256$ & $\mathbf{8}$ \\
\hline Burkholderia mallei & 32 & 8 & 16 & 64 \\
\hline
\end{tabular}




\begin{tabular}{|c|c|c|c|c|}
\hline Neisseria polysaccharea & 32 & 32 & $\mathbf{1 6}$ & $\mathbf{1 6}$ \\
\hline Pasteurella lymphangitidis & 64 & 64 & $>256$ & $\mathbf{8}$ \\
\hline Stenotrophomonas maltophila & $>256$ & 16 & 16 & 64 \\
\hline \hline
\end{tabular}

Compound $2\left[\mathrm{Ag}(8-\mathrm{nqu})_{2}\right] \mathrm{NO}_{3} \cdot \mathrm{H}_{2} \mathrm{O}$ shows antimicrobial activities against all the test pathogens, whereas $\left[\mathrm{Ag}(5-\mathrm{nqu})_{2}\right] \mathrm{NO}_{3} 1$ shows high antimicrobial activities only against Micrococcus luteus (MIC, $8 \mu \mathrm{g} / \mathrm{ml}$ ). Compound 6, $\left[\mathrm{Ag}(\mathrm{quCOOH})_{2}\right] \mathrm{NO}_{3}$, is more active against Gram-positive bacteria and has higher activities than SS against Corynebacterium sp1, Burkholderia mallei, Stenotrophomonas maltophila, and Bacillus sp2.

Given the concerns about the development of silver-resistant bacteria, it is also important to evaluate the silver efficiency of each compound by calculating the MIC in terms of $\mu \mathrm{g} \mathrm{Ag} / \mathrm{ml}$. In this respect, compound 2 performs slightly better than SS against this set of test organisms. The average MICs are: $4.6 \mu \mathrm{g} \mathrm{Ag} / \mathrm{ml}$ for 2 and $5.6 \mu \mathrm{g} \mathrm{Ag} / \mathrm{ml}$ for SS. The complete data are provided in the Supporting Information (Table S1).

In an additional experiment using standard strains of Staphylococcus aureus, Pseudomonas aeruginosa, Proteus mirabilis, and Streptococcus pyogenes, compound $\mathbf{1}$ performed much better, showing lower average MIC values than silver nitrate $(6 \mu \mathrm{g} \mathrm{Ag} / \mathrm{ml}$ vs. $18 \mu \mathrm{g} \mathrm{Ag} / \mathrm{ml}$, for compound 1 vs. $\mathrm{AgNO}_{3}$ ). 
Table 15: Antibacterial activities of compound $\mathbf{1}$ and $\mathrm{AgNO}_{3}$ presented as MICs $(\mu \mathrm{g} / \mathrm{ml})$.

\begin{tabular}{|c|c|c|}
\hline \multirow{2}{*}{ Test organism } & \multicolumn{2}{|c|}{ Compound } \\
\cline { 2 - 3 } & $\mathbf{1}$ & $\mathbf{A g N O}_{\mathbf{3}}$ \\
\cline { 2 - 3 } & \multicolumn{2}{|c|}{$\mathbf{M I C}(\mathbf{\mu g} / \mathbf{m l})$} \\
\hline \hline Staphylococcus aureus & $\mathbf{1 9}$ & 25 \\
\hline Pseudomonas aeruginosa & $\mathbf{1 9}$ & 38 \\
\hline Proteus mirabilis & $\mathbf{3 8}$ & 76 \\
\hline Streptococcus pyogenes & $\mathbf{3 8}$ & 154 \\
\hline
\end{tabular}

Since not only MIC values are important in evaluating the potential of an antimicrobial compound, we also evaluated the time period over which a solution retained its ability to kill all the bacteria. For treatment with solutions of compound $\mathbf{1}$ or $\mathrm{AgNO}_{3}$ at 5-times and 2-times the measured MICs (in Table 15), we saw no significant bacterial growth of $S$. aureus(as assessed by optical density of the culture at $650 \mathrm{~nm}$ ) for up to 24 hours, although compound 1 tended to be the better inhibitor. When the concentrations of the antibacterial agents were decreased to the MIC, $\mathrm{AgNO}_{3}$ seemed to perform better in terms of bacterial killing, although both compounds still showed good inhibition of bacterial growth compared to the growth curve for the non-inhibited bacteria. At $50 \%$ of the MIC, some growth of the bacteria was detected, although this growth was still considerably poorer that that or the untreated bacteria(Figure S9).

Some caution must be taken in interpreting the present results. While the data reported here are averages of a number of tests, bacterial strains are not well-defined chemical samples, which means that many more tests are needed for verification. Experiments such as those reported here give only preliminary indications as to clinical relevent antimcrobial activities.

Recently, the antibacterial activities of some $\mathrm{Ag}(\mathrm{I})$ compounds that contain other quinolinetype ligands have been evaluated. Zhang et $a l^{27}$ investigated three $[\mathrm{Ag}((8$-pyridin-3yl)methylthio)quinoline) $]^{+}$compounds with different counter-ions to assess the MICs; higher activities against $S$. aureus and $P$. aeruginosa were recorded for $\mathrm{CF}_{3} \mathrm{CO}_{2}{ }^{-}$than for $\mathrm{NO}_{3}{ }^{-}$and $\mathrm{CF}_{3} \mathrm{SO}_{3}{ }^{-}$. Complexes with Ag-S bonds have been reported and reviewed recently. For example, $\mathrm{Na}[\mathrm{Ag}$ (3-(2-methoxyphenyl)-2-sulfanylpropenoato)] showed good activity against both $S$. aureus and resistant $P$. aeruginosa (MIC, $12.5 \mu \mathrm{g} / \mathrm{ml}$ ). ${ }^{28}$ Nomiya and collaborators 
have reported on the antibacterial properties of many $\mathrm{Ag}(\mathrm{I}) \ldots \mathrm{N}$ compounds.$^{29}$ For example, $\left[\mathrm{Ag}(1,2,4-\text { triazole) }]_{n}\right.$ showed good activity against $P$. aeruginosa (MIC, $7.9 \mu \mathrm{g} / \mathrm{ml}$ ), albeit weaker activity against $S$. aureus (MIC, $125 \mu \mathrm{g} / \mathrm{ml}$ ). In addition, $\left[[\mathrm{Ag}(\mathrm{L}-\mathrm{histidine})]_{2}\right]_{n}$ was active against $P$. aeruginosa and $S$. aureus (MICs of $15.7 \mu \mathrm{g} / \mathrm{ml}$ and $62.5 \mu \mathrm{g} / \mathrm{ml}$, respectively), as was $\left.[\mathrm{Ag} \text { (imidazole) })_{2}\right]\left(\mathrm{NO}_{3}\right)$ (MICs of $7.9 \mu \mathrm{g} / \mathrm{ml}$ and $15.7 \mu \mathrm{g} / \mathrm{ml}$, respectively), while the compound $[\mathrm{Ag}(1,2,3 \text {-triazole })]_{n}$ showed no activity against either of these bacterial species. Studies of N-heterocyclic silver-carbene compounds have also shown some promise, ${ }^{5 c, 30}$ and a recent report by Abarca et al. on carboxylic acid-substituted pyridines showed MIC values in the range of $4-6 \mu \mathrm{g} \mathrm{Ag} / \mathrm{ml}^{7 \mathrm{f}}$

Recently, we tested a number of $\mathrm{Ag}(\mathrm{I})$ coordination compounds with pyridine ${ }^{19}$ and nicotinate-type ${ }^{8}$ ligands against MDRS isolated from diabetic foot ulcers in the clinical setting. These compounds showed high antibacterial activities and outperformed the commonly used silver sulfadiazine. Compounds $\left[\mathrm{Ag}(4,5 \text {-diazafluorene-9-one })_{2}\right] \mathrm{NO}_{3},{ }^{10 \mathrm{~b}}$ $\left[\mathrm{Ag}(2 \text {-amino-3-methylpyridine })_{2}\right] \mathrm{NO}_{3}$, and $[\mathrm{Ag}$ (pyridine-2-carboxaldoxime $\left.) \mathrm{NO}_{3}\right]^{10 \mathrm{a}}$ showed higher activities than most $\beta$-lactam antibiotics, in addition to their DNA binding properties.

\section{Electrospray ionization mass spectrometry (ESI-MS)}

High-resolution ESI-MS was used to investigate the different ionic species in solution, giving clues as to the stability of the compound under the experimental conditions (spraying, vaporization and ionization). Two representative examples were tested; compound 3 (Ag:L = $1: 1)$; and compound $6(\mathrm{Ag}: \mathrm{L}=1: 2)$. A very strong peak at $\mathrm{m} / \mathrm{z} 515.0166$ was observed for compound 3, indicating the presence of the cation $\left[\mathrm{Ag}(\mathrm{mnqu})_{2}\right]^{+}$(calculated $\mathrm{m} / \mathrm{z} 515.01$ for $\mathrm{C}_{20} \mathrm{H}_{16} \mathrm{AgN}_{4} \mathrm{O}_{6}$ ) in solution, which differs from the cation present in the solid state $[\mathrm{Ag}(\mathrm{mnqu})]^{+}$. For compound $\mathbf{6}$, a very strong peak at $\mathrm{m} / \mathrm{z} 453.0040$ was observed, which is consistent with the theoretical $\mathrm{m} / z$ (453.00 for $\mathrm{C}_{20} \mathrm{H}_{14} \mathrm{AgN}_{2} \mathrm{O}_{4}$ ) calculated for the cation $\left[\mathrm{Ag}(\mathrm{quCOOH})_{2}\right]^{+}$, confirming the presence of such ions in solution as well as in the solid state.

\section{NMR titrations}

Recently, the complexation behaviour of $\mathrm{Ag}(\mathrm{I})$ ions with different ligands in solution have 
been investigated by ${ }^{1} \mathrm{H}-\mathrm{NMR}$ titrations in various solvents. ${ }^{31}$ In these studies, the shift changes were usually small, for example in the study of the 1-methyl-1H-1,2,4-triazole ligand in the order of $0.05 \mathrm{ppm}$ totally, ${ }^{31 \mathrm{~d}}$ and the spectra are all average spectra, indicating, as expected, rapid exchange on the NMR timescale.

Two complexes were chosen for the NMR titrations: the $\operatorname{Ag}(\mathrm{I})$ complex of 5-nitroquinoline, 1, which has the shortest Ag-N bond in the solid state [2.142(2) $\AA$ ]; and the $\mathrm{Ag}(\mathrm{I})$ complex 8nitroquinoline, 2, which has the longest Ag-N bond [2.336(2) $\AA$ ]. Dilute solutions (50 mM) of the ligand in DMSO were titrated with silver nitrate solutions of the same concentrations up to 1.3 equivalents, and the proton chemical shifts were monitored. The results are shown in Figure 18.

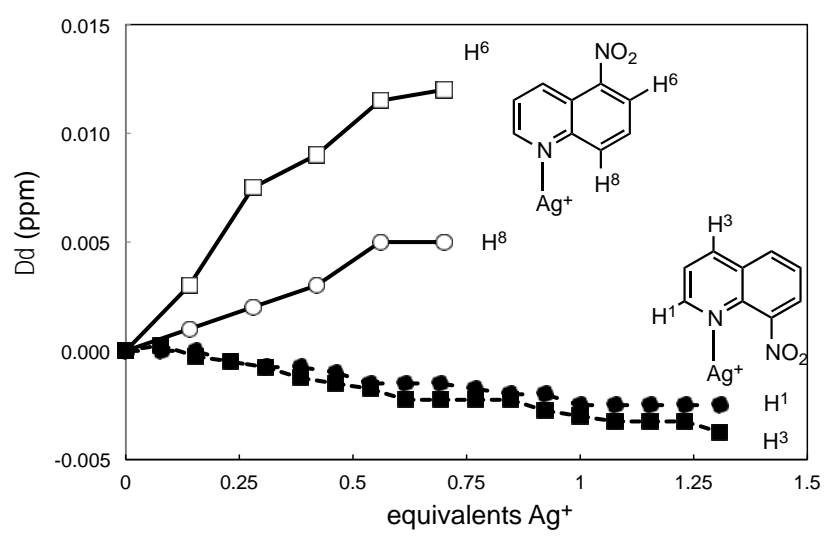

Figure 18: NMR titrations of 5-nitroquinoline (empty symbols) and 8-nitroquinoline (filled symbols) in DMSO (corresponding to compounds $\mathbf{1}$ and $\mathbf{2}$, respectively) with $\mathrm{AgNO}_{3}$ in DMSO. The most prominent shift changes are shown together with a tentative assignment of the corresponding peaks (5-nuq: $\mathrm{H} 68.445 \mathrm{ppm}$ and $\mathrm{H} 88.460 \mathrm{ppm}$, 8nqu: H3 8.265 ppm and H1 9.041 ppm)

Although the chemical shift effects are very small, they seem to indicate that complex $\mathbf{1}$ forms more readily than complex 2 . The changes in chemical shifts $(\Delta \delta)$ for 5-nitroquinoline level off and seem to become constant after 0.5 equivalents, in agreement with the formation of a 1:2 complex, as detected by MS for compounds $\mathbf{3}$ and $\mathbf{6}$, whereas for 8-nitroquinoline the NMR titration does not give any indication of complexation. This indicates a much weaker interaction between the $\mathrm{Ag}^{+}$ions and 8-nitroquinoline, in line with the $14 \%$ increase in Ag-N bond lengths. 
Whether or not 1:1 complex formation is important at lower Ag to ligand concentration ratios cannot be resolved based on these data. Nevertheless, we note that for compound $\mathbf{6}$, the MS data with stoichiometry of 1:1 still show exclusive 1:2 complex formation.

\section{Conclusions}

From the above-mentioned results we conclude that different substitutions have strong influences on the structural aspects, as well as the biological activities of $\mathrm{Ag}(\mathrm{I})$ compounds with quinolinetype ligands. The compounds tested show higher activities against clinical isolates of Burkholderia mallei, as compared with silver sulfadiazine. Moreover, compounds $\mathbf{2}$ and $\mathbf{6}$ have higher activities against Corynebacterium sp1 and Stenotrophomonas maltophila, and compound $\mathbf{6}$ is active against Bacillus sp2.

In complementary tests, the activities of compound $\mathbf{1}$ and silver nitrate against standard (nonclinical isolates) Staphylococcus aureus, Pseudomonas aeruginosa, Proteus mirabilis, and Streptococcus pyogenes isolates were compared. Compound $\mathbf{1}$ outperformed $\mathrm{AgNO}_{3}$ both on a $\mu \mathrm{g} / \mathrm{ml}$ basis and on a $\mu \mathrm{g} \mathrm{Ag} / \mathrm{ml}$ basis. Moreover, solutions of $\mathbf{1}$ retained antibacterial activity against $S$. aureus for at least 24 hours, as shown in the kill-time experiments.

However, it is important to stress the difference between chemical research and biological testing. Many more repetitions are needed when using biological samples, and test such as those reported here can give only preliminary indications. Compounds $\mathbf{1}$ and $\mathbf{2}$ are currently undergoing further evaluations in our laboratory.

From a structural perspective, the notion that the nitrate counter-ion in crystals of $\mathrm{AgL}_{\mathrm{n}}^{+}$ compounds will either be hydrogen-bonded, or in the absence of strong hydrogen bond donors, coordinate to the silver ion, has to be re-evaluated. Specific weak hydrogen bonding patterns, as observed for compound $\mathbf{5}$, or interactions with polar groups, as observed for compound $\mathbf{1}$ also have to be considered.

The ESI-MS results suggest a strong preference for $\mathrm{AgL}_{2}$ coordination in solution, even if the solid-state structure suggests otherwise. The NMR titrations indicate weaker complexation of 8nitroquinoline, as compared to 5-nitroquinoline. 


\section{Acknowledgments}

This work was supported by the Kristina Stenborgs Stiftelse, Magnus Bergvalls Stiftelse, and Kungliga Vetenskaps och Vitterhetssamhället i Göteborg. The authors thank Mr. Jakub Večerka for X-ray data collection and treatment and Mrs. Ritva Romppanen for her skillful technical assistance with the ESI-MS measurements.

\section{Supporting Information Available}

X-ray crystallographic data of compounds 1-6 in CIF format, IR data, classical thermal ellipsoid plots of all compounds, experimental and simulated XRD of compound 1, and the silver efficiencies of the anti-bacterial activities for compounds 1-3 and $\mathbf{6}$. This material is available free of charge via the Internet at http://pubs.acs.org.

\section{References}

(1) ECDC/EMEA JOINT TECHNICAL REPORT The bacterial challenge: time to react EMEA/576176/2009, ISBN 978-92-9193-193-4, doi 10.2900/2518, European Centre for Disease Prevention and Control, 2009.

(2) (a) Klasen, H. J. Burns 2000, 26, 131; $\quad$ (b) Klasen, H. J. Burns 2000, 26, 117; (c) Edwards-Jones, V. Lett. Appl. Microbiol. 2009, 49, 147.

(3) (a) Bergin, S.; Wraight, P. Cochrane Database of Systematic Reviews 2006; _ _ (b)

Storm-Versloot, M. N.; Vos, C. G.; Ubbink, D. T.; Vermeulen, H. Cochrane Database of Systematic Reviews 2010; - (c) Vermeulen, H.; van Hattem, J. M.; Storm-Versloot, M. N.; Ubbink, D. T. Cochrane Database of Systematic Reviews 2007; $\quad$ (d) Atiyeh, B. S.; Costagliola, M.; Hayek, S. N.; Dibo, S. A. Burns 2007, 33, 139; (e) Hooper, S. J.; Williams, D. W.; Thomas, D. W.; Hill, K. E.; Percival, S. L. Ost. Wound Man. 2012, 58, 16; (f) Toy, L. W.; Macera, L. J. Amer. Acad. Nurse Pract. 2011, 23, 183. 
(5) (a) Coyle, B.; McCann, M.; Kavanagh, K.; Devereux, M.; McKee, V.; Kayal, N.; Egan, D.; Deegan, C.; Finn, G. J. J. Inorg. Biochem. 2004, 98, 1361; $\quad$ (b) Liu, W. K.; Bensdorf, K.; Hagenbach, A.; Abram, U.; Niu, B.; Mariappan, A.; Gust, R. Eur. J. Med. Chem. 2011, 46, 5927; (c) Patil, S.; Deally, A.; Gleeson, B.; Mueller-Bunz, H.; Paradisi, F.; Tacke, M. Appl. Organomet. Chem. 2010, 24, 781.

(6) Panyala, N. R.; Pena-Mendez, E. M.; Havel, J. J. Appl. Biomed. 2008, 6, 117.

(7) (a) Panzner, M. J.; Hindi, K. M.; Wright, B. D.; Taylor, J. B.; Han, D. S.; Youngs, W. J.; Cannon, C. L. Dalton Trans. 2009, 7308; ～(b) Ruan, B. F.; Tian, Y. P.; Zhou, H. P.; Wu, J. Y.; Liu, Z. D.; Zhu, C. H.; Yang, J. X.; Zhu, H. L. J. Organomet. Chem. 2009, 694, 2883; $\quad$ (c) Kasuga, N. C.; Takagi, Y.; Tsuruta, S.-i.; Kuwana, W.; Yoshikawa, R.; Nomiya, K. Inorg. Chim. Acta 2011, 368, 44; (d) Kharat, A. N.; Bakhoda, A.; Foroutannejad, S.; Foroutannejad, C. Z. Anorg. Allg. Chemie 2011, 637, 2260; (e) Pettinari, C.; Marchetti, F.; Lupidi, G.; Quassinti, L.; Bramucci, M.; Petrelli, D.; Vitali, L. A.; da Silva, M.; Martins, L.; Smolenski, P.; Pombeiro, A. J. L. Inorg. Chem. 2011, 50, 11173; (f) Abarca, R.; Gomez, G.; Velasquez, C.; Paez, M. A.; Gulppi, M.; Arrieta, A.; Azocar, M. I. Chin. J. Chem. 2012, 30, 1631; (g) Ando, S.; Hioki, T.; Yamada, T.; Watanabe, N.; Higashitani, A. J. Mat. Science 2012, 47, 2928; (h) Kasuga, N. C.; Yoshikawa, R.; Sakai, Y.; Nomiya, K. Inorg. Chem. 2012, 51, 1640; (i) Pettinari, C.; Marchetti, F.; Lupidi, G.; Quassinti, L.; Bramucci, M.; Petrelli, D.; Vitali, L. A.; Guedes da Silva, M. F. t. C.; Martins, L.s. M. D. R. S.; Smoleñ $\approx$ Ñski, P.; Pombeiro, A. J. L. Inorg. Chem. 2011, Formatted: Font: (Default) Times 50,11173 .

(8) Abu-Youssef, M. A. M.; Dey, R.; Gohar, Y.; Massoud, A. A.; Öhrström, L.; Langer, V. Inorg. Chem. 2007, 46, 5893.

(9) (a) Abu-Youssef, M. A. M.; Langer, V.; Öhrström, L. Chem. Commun. 2006, 1082-1084;

(b) Massoud, A.-s. a. A.; Langer, V. Acta Crys. C 2009, 65, m198; (c) Massoud, A. A.; Langer, V.; Abu-Youssef, M. A. M. Acta Crys. C 2009, 65, m352.

(10) (a) Abu-Youssef, M. A. M.; Soliman, S. M.; Langer, V.; Gohar, Y. M.; Hasanen, A. A.; Makhyoun, M. A.; Zaky, A. H.; Öhrström, L. R. Inorg. Chem. 2010, 49, 9788; （b) Massoud, A. A.; Gohar, Y.; Langer, V.; Lincoln, P.; Svensson, F. R.; Jänis, J.; Haukka, M.; Jonsson, F.; Aneheim, E.; Abu-Youssef, M. A. M.; Öhrström, L. New J. Chem., 2011, 35, 640. 
(11) (a) Anders, J. C.; Chung, H.; Theoharides, A. D. Fund. Appl. Tox. 1988, 10, 270; (b) Dutta, A. K.; Avery, B. A.; Wyandt, C. M. J. Chrom. A 2006, 1110, 35; $\quad$ (c) Deshpande, S. S.; Sheridan, R. E.; Adler, M. Toxicon 1997, 35, 433.

(12) Birkholz, D. A.; Coutts, R. T.; Hrudey, S. E.; Danell, R. W.; Lockhart, W. L. Water Research 1990, 24, 67.

(13) (a) Clausen, H. F.; Chevallier, M. S.; Spackman, M. A.; Iversen, B. B. New J. Chem 2010, 34, 193; $\quad$ (b) McKinnon, J. J.; Spackman, M. A.; Mitchell, A. S. Acta Cryst. B 2004, B60, 627; $\quad$ (c) Spackman, M. A.; McKinnon, J. J. CrystEngComm 2002, 4, 378;

Spackman, M. A.; Jayatilaka, D. CrystEngComm 2009, 11, 19.

(14) Allen, F. Acta Cryst.B 2002, 58, 380.

(15) Du, M.; Zou, R.-Q.; Zhong, R.-Q.; Xu, Q. Inorg. Chim. Acta 2008, 361, 1555.

(16) Batten, S. R.; Champness, N. R.; Chen, X.-M.; Garcia-Martinez, J.; Kitagawa, S.; Öhrström, L.; O'Keeffe, M.; Suh, M. P.; Reedijk, J. CrystEngComm 2012.

(17) Steel, P. J.; Fitchett, C. M. Coord. Chem. Rev. 2008, 252, 990.

(18) Khlobystov, A. N.; Blake, A. J.; Champness, N. R.; Lemenovskii, D. A.; Majouga, A. G.; Zyk, N. V.; Schroder, M. Coord. Chem. Rev. 2001, 222, 155.

(19) Abu-Youssef, M. A. M.; Langer, V.; Öhrström, L. Dalton Trans. 2006, 2542.

(20) (a) Ramstedt, M.; Ekstrand-Hammarstrom, B.; Shchukarev, A. V.; Bucht, A.; Osterlund, L.; Welch, M.; Huck, W. T. S. Biomaterials 2009, 30, 1524; $\quad$ (b) Brett, D. W. Ost. Wound Man. 2006, 52, 34 .

(21) Siemens analytical X-ray Instruments Inc.: Madison,Wisconsin, USA, 1995.

(22) Sheldrick, G. M.; University of Göttingen: Göttingen, Germany, 1996.

(23) Sheldrick, G. M.; Acta. Cryst. A64, 112-122 2008.

(24) Bowmaker, G. A.; Effendy; Lim, K. C.; Skelton, B. W.; Sukarianingsih, D.; White, A. H. Inorg. Chim. Acta 2005, 358, 4342.

(25) Janiak, C. J. Chem. Soc., Dalton Trans. 2000, 3885.

(26) Bondi, A. J. Phys. Chem. 1964, 68, 441.

(27) Zhang, J.-A.; Pan, M.; Zhang, J.-Y.; Zhang, H.-K.; Fan, Z.-J.; Kang, B.-S.; Su, C.-Y. Polyhedron 2009, 28, 145.

(28) Barreiro, E.; Casas, J. S.; Couce, M. D.; Sanchez, A.; Seoane, R.; Sordo, J.; Varela, J. M.; Vazquez-Lopez, E. M. Eur. J. Med. Chem. 2008, 43, 2489. 
(29) Kasuga, N. C.; Yamamoto, R.; Hara, A.; Amano, A.; Nomiya, K. Inorg. Chim. Acta 2006, 359, 4412.

(30) Patil, S.; Claffey, J.; Deally, A.; Hogan, M.; Gleeson, B.; Mendez, L. M. M.; MuellerBunz, H.; Paradisi, F.; Tacke, M. Eur. J. Inorg. Chem. 2010, 1020.

(31) (a) Constable, E. C.; Housecroft, C. E.; Neuburger, M.; Reymann, S.; Schaffner, S. Aus. J. Chem. 2008, 61, 847; $\quad$ (b) Habata, Y.; Yamashita, Y.; Akabori, S. J. Chem. Soc., Dalton Trans. 2001, 966; $\quad$ (c) Holzberger, A.; Holdt, H. N.; Kleinpeter, E. J. Phys. Org. Chem.2004, 17, 257; (d) Megger, D. A.; Koesters, J.; Hepp, A.; Mueller, J. Eur. J. Inorg. Chem. 2010, 4859; (e) Wenzel, M.; Wichmann, K.; Gloe, K.; Gloe, K.; Buschmann, H.-J.; Otho, K.; Schroeder, M.; Blake, A. J.; Wilson, C.; Mills, A. M.; Lindoy, L. F.; Plieger, P. G. CrystEngComm 2010, 12, 4176; (f) Wimberg, J.; Scheele, U. J.; Dechert, S.; Meyer, F. Eur. J. Inorg. Chem 2011, 3340. 


\section{Table of Contents synopsis}

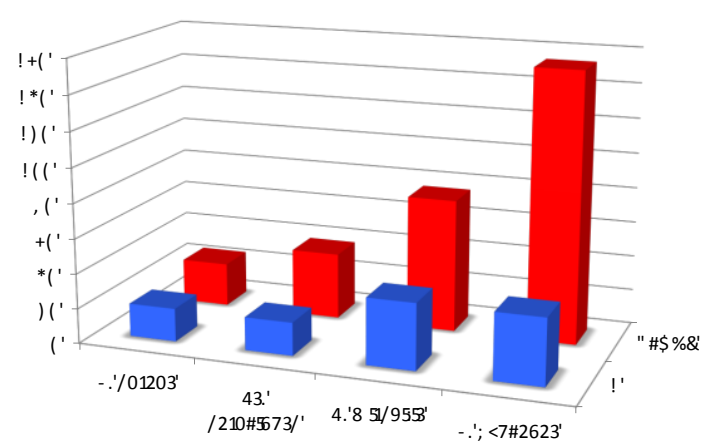

[ $\mathrm{Ag}$ (5-nitroquinoline $\left.)_{2}\right] \mathrm{NO}_{3} \mathbf{1}$ performed significantly better than $\mathrm{AgNO}_{3}$ in an $\mathrm{MIC}$ test against four standard bacterial strains. The investigation of this series (1-6) of $\mathrm{Ag}(\mathrm{I})$ quinoline compounds is complemented by X-ray diffraction and solution studies, as well as testing on clinically isolated MDRS. The role of intermolecular interactions in determining the $\operatorname{Ag}(\mathrm{I})$ coordination number in the solid state is highlighted. 